\title{
Solidification Enhancement in a Triple-Tube Latent Heat Energy Storage System Using Twisted Fins
}

\author{
Xinguo Sun ${ }^{1, *}$, Jasim M. Mahdi ${ }^{2} \mathbb{D}$, Hayder I. Mohammed ${ }^{3} \mathbb{D}$, Hasan Sh. Majdi ${ }^{4} \mathbb{D}$, Wang Zixiong ${ }^{5}$ and \\ Pouyan Talebizadehsardari $6, *$ (D)
}

1 Jiangsu Smart Factory Engineering Research Centre, College of Management and Engineering, Huaiyin Institute of Technology, Huai'an 223003, China

2 Department of Energy Engineering, University of Baghdad, Baghdad 10071, Iraq; jasim@siu.edu

3 Department of Physics, College of Education, University of Garmian, Kurdistan, Kalar 46021, Iraq; hayder.i.mohammad@garmian.edu.krd

4 Department of Chemical Engineering and Petroleum Industries, Al-Mustaqbal University College, Babylon 51001, Iraq; hasanshker1@gmail.com

5 China Water Resources Pearl River Planning Surveying \& Designing Co, Ltd., Guangzhou 510610, China; xiongwz2020@126.com

6 Centre for Sustainable Energy Use in Food Chains, Institute of Energy Futures, Brunel University London, Kingston Lane, Uxbridge UB8 3PH, UK

* Correspondence: sunxinguo2021@163.com (X.S.); pouyan.talebizadehsardari@brunel.ac.uk (P.T.)

Citation: Sun, X.; Mahdi, J.M.; Mohammed, H.I.; Majdi, H.S.; Zixiong, W.; Talebizadehsardari, P. Solidification Enhancement in a Triple-Tube Latent Heat Energy Storage System Using Twisted Fins. Energies 2021, 14, 7179. https:// doi.org/10.3390/en14217179

Academic Editor: Luisa F. Cabeza

Received: 16 September 2021

Accepted: 28 October 2021

Published: 1 November 2021

Publisher's Note: MDPI stays neutral with regard to jurisdictional claims in published maps and institutional affiliations.

Copyright: (c) 2021 by the authors. Licensee MDPI, Basel, Switzerland. This article is an open access article distributed under the terms and conditions of the Creative Commons Attribution (CC BY) license (https:// creativecommons.org/licenses/by/ $4.0 /)$.

\begin{abstract}
This work evaluates the influence of combining twisted fins in a triple-tube heat exchanger utilised for latent heat thermal energy storage (LHTES) in three-dimensional numerical simulation and comparing the outcome with the cases of the straight fins and no fins. The phase change material (PCM) is in the annulus between the inner and the outer tube, these tubes include a cold fluid that flows in the counter current path, to solidify the PCM and release the heat storage energy. The performance of the unit was assessed based on the liquid fraction and temperature profiles as well as solidification and the energy storage rate. This study aims to find suitable and efficient fins number and the optimum values of the Re and the inlet temperature of the heat transfer fluid. The outcomes stated the benefits of using twisted fins related to those cases of straight fins and the no-fins. The impact of multi-twisted fins was also considered to detect their influences on the solidification process. The outcomes reveal that the operation of four twisted fins decreased the solidification time by $12.7 \%$ and $22.9 \%$ compared with four straight fins and the no-fins cases, respectively. Four twisted fins improved the discharging rate by $12.4 \%$ and $22.8 \%$ compared with the cases of four straight fins and no-fins, respectively. Besides, by reducing the fins' number from six to four and two, the solidification time reduces by $11.9 \%$ and $25.6 \%$, respectively. The current work shows the impacts of innovative designs of fins in the LHTES to produce novel inventions for commercialisation, besides saving the power grid.
\end{abstract}

Keywords: triple-tube heat exchanger; twisted fin array; phase change material; thermal energy storage; solidification

\section{Introduction}

The electrical and power generation equipment's application generally faces a considerable heat flux [1-3]. The operation of these machines may be thermally affected if the applicable thermal control measure is absent, causing a failure in the operation process [4-6]. Latent heat thermal energy storage (LHTES) could consider as a passive heat control measure for related thermal applications $[7,8]$. The phase change material (PCM) based in the LHTES can hold the temperature at a constant value by releasing or absorbing heat during the phase change process [9-11]. The simple structure, high and constant performance, and no extra power spending, make the LHTES appropriate for space application [12,13]. Still, a major concern for the LHTES system is PCM's minimal thermal 
efficiency, which decreases the phase change rate [14-17]. Researchers developed several techniques to improve the heat transfer rate of such systems, including the expansion of the heat transfer surface area [18-20], adding micro or nano-sized particles [21-24], using cascade layer PCM [25], encapsulation techniques [26,27], changing the location of the heat transfer fluid (HTF) channel [28-30], fins combinations [31-33], conductive foams [34-36], and using magnetic fields $[37,38]$.

A lot of studies related to enhancing the thermal performance in the solidification process have been achieved [39]. Tao [40] was the first researcher to investigate the solidification process in cylindrical geometry. He developed a numerical model to predict interface moving issues during the phase change process. Gortych et al. [41] experimentally and numerically analysed the discharge process of the PCM located in a horizontal annular channel. They assumed a constant wall temperature, which is not a real condition, and they detected a moderate range of the natural convection coefficient. Abdollahzadeh and Esmaeilpour [42] investigated the thermal energy storage (TES) with a wavy wall, and nanofluid used as HTF. They found that the configuration of the system and the nanofluid have great influences on the thermal performance of the system. Shahsavar et al. [43] examined the effect of the wavy channel combined with the metal foam on the latent heat system (LHS). They found that the system configuration and the porous medium have a considerable effect on the thermal performance of the solidification process due to increasing the heat transfer surface area and enhancing the average thermal conductivity of the system. Choi and Kim [44] evaluated the circular fins for the discharging improvement in the LHS. Their work stated that the fins enhance the heat transfer coefficient by 3 times over the case without fins. Wang et al. [45] numerically studied the solidification process in a 2-D zigzag shape heat exchanger. Unlike the inlet velocity, they found that the average velocity of the HTF has a noticeable influence on the thermal performance. Sardari et al. [46] studied the modification of the LHS using a zigzag configuration. They confirm that the unit with the zigzag angle of $60^{\circ}$ accelerated the storage time by $1 / 3$ times over the time of the case with a $30^{\circ}$ zigzag angle.

Applying double and triple pipe as the heat exchanger has been widely used in the TES to steady the effects of various parameters such as fins, temperature, and velocity of HTF $[47,48]$. Shokouhmand and Kamkari [49] numerical evaluated the charging process of the PCM in the double pipe heat exchanger. They stated that the phase change process is strongly affected by the fins placed in the inner tube. Bazai et al. [50] numerically studied an elliptical tube implanted in an annulus channel, they investigated the effects of various aspect ratios and the angular position of the inner ellipse diameters during the charging process. They found that the maximum charging rate accelerated by $61 \%$ and the system performance improved by $26 \%$. Shahsavar et al. [51] numerically studied the phase change processes in a wavy double-pipe LHTES unit. They found that the essential time to charge and discharge the PCM decreases by $29 \%$ and $58 \%$, respectively, utilising wavy tubes compared with the straights. In a separate study, Shahsavar et al. [52] assessed the efficiency of the phase change process in a wavy double-channel TES system. Increasing the inlet temperature, average velocity, and wave amplitude increases the performance of the system. Xu et al. [53,54] examined a horizontal double-pipe TES combined with a porous medium and optimised the position of the porous injected in the system. They found that the system with a partially filled foam at the base part has the same effect as the system with totally filled by the foam with $80 \%$ enhancement of the melting rate. Researchers also applied triple pipe in the TES heat exchanger. Ghalambaz et al. [55] studied the impact of the fins array in a triple-tube LHTES during the melting process. They found that the charging rate for the case of utilising four straight fins was 8.3\% lower than that compared with the fins-less case. In two separate works, Mahdi et al. [56,57] studied the performance of the charging rate of the PCM in a triplex tube system. Li et al. [58] studied the effect of the metal foam and nanoparticles on the PCM in a triplex tube LHS. The main outcome of their work was that increasing the loading of nanoparticles or decreasing the porosity of the porous medium accelerates the phase change rate of the PCM. 
Fins are considered the best technique to solve the issue of the low thermal conductivity of the PCM and improve the general heat transfer performance in the LHS. Longitudinal, annular, pin, triangular, radial, array, and tree-like fins are the shapes studied by the researcher [59]. Mat et al. [60] utilised a longitudinal fin in the LHS, and they detected a 58\% reduction in the phase change time at the constant HTF velocity and $86 \%$ under a constant inlet temperature of the HTF. Darzi et al. [61] numerically analysed the solidification process for the PCM in the TES combined with radial fins. They stated that utilising fins increase the solidification process due to increasing the surface area of the heat transfer, and this effect diminishes during the melting process due to annihilation of the natural convection. Pizzolato et al. [62] detected an increase in the melting and solidification rates by $37 \%$ and $15 \%$, respectively, when high conductive fins were implanted in a small size TES. Y1ldiz et al. [63] studied the effect of the fins dimensions and structure (using tree-shaped fins) on the phase change rate, and they found that the rectangular shape has a stronger influence on the system. Yu et al. [64] studied the performance of the LHS using tree-shaped fins, they found that using such fins decreases the melting time by $27 \%$ and increases the heat storage rate by $45 \%$ than the conventional fins. Rathod and Banerjee [65] stated that the fins improve the TES with both charging and discharging processes. The main enhancements were found as $11 \%, 12 \%$, and $15 \%$ with utilising internal, internal with external, and external triangle fins over the case with longitudinal fins. The rectangular fins supply an improvement rate of $15 \%$ over the triangle fins when the evaluation of the fins' configuration is achieved by Abdulateef et al. [66]. Shahsavar et al. [67] examined the influence of the fins locations in the vertical pipe LHS for the charging and discharging systems. The time of the melting and solidification reduces by $41 \%$ and $10 \%$ by using a uniform fins array compared with the non-uniform array.

Twisted fins have been recently used to improve the heat transfer characteristics in heat exchangers [68]. Providing a higher heat transfer area in the length unit of the heat exchanger is the main advantage of twisted-fins implementation in heat exchangers. Moreover, they generate a swirling flow in the liquid phase, leading to an enhancement in flow mixing and thermal boundary layer disturbance which in turn increases the heat transfer [69]. There are limited studies in the literature on the use of twisted-fins array in latent heat storage systems. Ghalambaz et al. [9,55] studied the twisted-fin array as an advanced form for increasing the phase change rate of the PCM in the shell-and-tube unit during the melting process. They stated that in a double-tube heat exchanger after optimising the geometrical parameters of the fin [9], the use of five twisted fins array improves the melting rate by $42 \%$ and the storage rate by $63 \%$ compared with the case with straight longitudinal fins using similar geometrical parameters. In a triple-tube heat exchanger, they showed that the use of four twisted fins reduced the melting time and melting rate by $18 \%$ and $25 \%$, respectively, compared with the cases of using the same number of straight fins and no-fins considering a similar PCM mass.

In this study, three-dimensional numerical modelling of the PCM solidification process is simulated in a triplex tube LHS combined with twisted fins. The use of twisted fins along the inner perimeter of the annulus hosting the PCM in the triple-tube heat exchanger during the solidification is considered a new contribution to the existing literature. Fins are inserted into the PCM in the centre of the tube and located in a staggered alignment. According to the above comprehensive review, there is no published study regarding twisted-fins application in the triple-tube heat exchanger for intensifying the PCM solidification. It should be noted that the authors studied a similar geometry in their previous study [55] during the melting mode of the PCM and in this study, the solidification process is investigated as the process of heat transfer is different during the solidification compared with the melting due to natural convection especially for vertical geometries. Different simulations were run via ANSYS FLUENT 17.0 (Canonsburg, PA, USA) to evaluate the effectiveness of the innovative design of the fins compared to the base cases of straight fins and no-fins during the solidification. The main purpose was to find suitable and efficient fins number and the best values of the mass flow rate and the inlet temperature of the HTF. 
Liquid and temperature contour plots and solidification rates are analysed scientifically to evaluate the discharge process. The results of this work provide guidelines for the novel structure of latent heat storage units.

\section{Problem Description}

A triple-tube LHS system with twisted fins (Figure 1a) was investigated during the solidification process compared with no-fin and straight fin cases, shown in Figure 1. The system was positioned vertically, and the PCM region was located in the middle tube. Hot water with the uniform inlet temperature of 10,15 , and $20^{\circ} \mathrm{C}$ and Reynolds numbers of 500, 1000, and 1500 passed through the inner and outer tubes using RT35 as the PCM. Note that the Reynolds number is changed by the variation of inlet velocity of the HTF. The velocity of the HTF for the Reynolds number of 1000 is $0.055 \mathrm{~m} / \mathrm{s}$. The adiabatic outer tube was chosen to neglect heat loss from the system to the environment. A pressure outlet was applied for the outlet, and uniform inlet temperature and velocity were employed for the inlet. For the wall surfaces, the no-slip boundary condition was applied. Note that because of the advantages of counter-current flow directions for the working fluid to have a higher melting rate, this method was employed in this study [58]. The inner, middle, and outer diameters of the system were 20, 42, and $64 \mathrm{~mm}$, respectively. The thickness of the inner and middle tubes was considered $2 \mathrm{~mm}$, considering copper for the material of the fins and inner tube. To compare the effect of twisted fins addition with straight fins and no-fin cases, four copper fins were added to the system which the fins were externally and internally attached to the inner and the middle tubes, respectively, as shown in Figure 1. Then, a different number of 2, 4, and 6 fins with twisted configurations were also investigated. The fin pitch for the case of twisted fins was $3 \mathrm{~cm}$. The initial temperature of the PCM is considered $50{ }^{\circ} \mathrm{C}$. It is worth noting that this work was achieved with analysis of the numerical results only, and no experiment works were included.

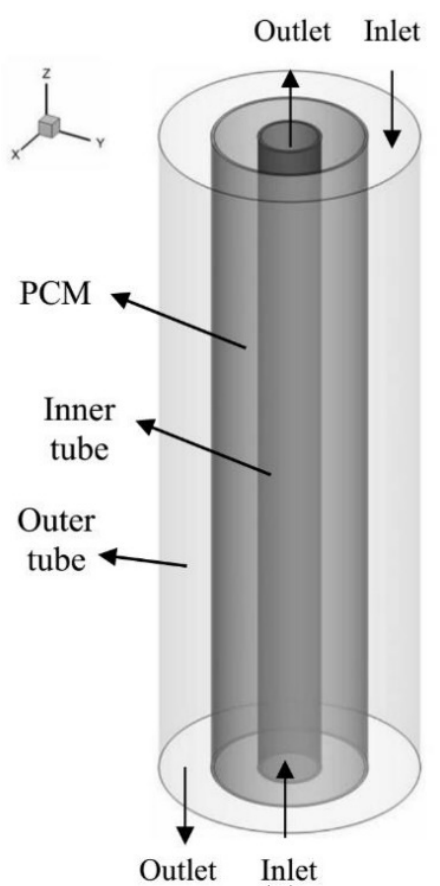

(a)

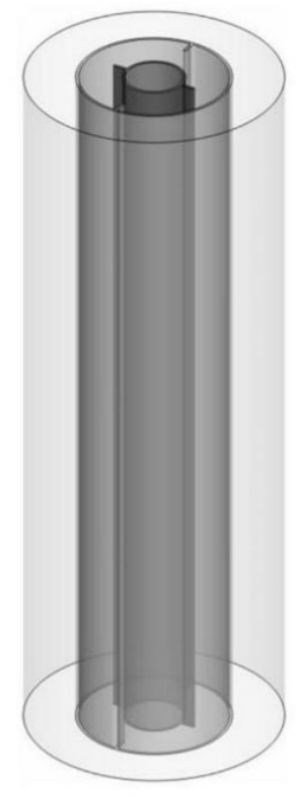

(b)

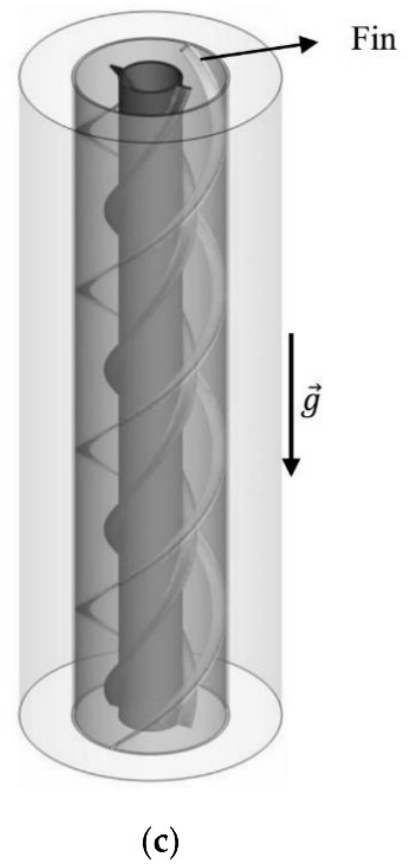

(c)

Figure 1. The schematic of the proposed double-tube heat exchanger with twisted fins using: (a) no fins, (b) straight fins, and (c) twisted fins.

The properties of RT35 as the employed PCM are presented in Table 1. 
Table 1. Thermo-physical properties of RT35 [70].

\begin{tabular}{cc}
\hline Property & RT35 \\
\hline Specific heat $(\mathrm{kJ} / \mathrm{kg} \mathrm{K})$ & 2 \\
Viscosity $(\mathrm{Pa} \mathrm{s})$ & 0.023 \\
Heat of fusion $(\mathrm{kJ} / \mathrm{kg})$ & 170 \\
Liquidus temperature $\left({ }^{\circ} \mathrm{C}\right)$ & 35 \\
Density $\left(\mathrm{kg} / \mathrm{m}^{3}\right)$ & 815 \\
Thermal conductivity $(\mathrm{W} / \mathrm{m} \mathrm{K})$ & 0.2 \\
Solidus temperature $\left({ }^{\circ} \mathrm{C}\right)$ & 29 \\
Thermal expansion coefficient $(1 / \mathrm{K})$ & 0.0006 \\
\hline
\end{tabular}

\section{Mathematical Modeling}

To calculate the phase change process numerically, the enthalpy-porosity approach was employed where, in each cell, the porosity and the liquid fraction were considered equal [71]. The Newtonian free convection flow of melted PCM was generated because of the buoyancy forces, which were transient and placed in the laminar flow regime because of the range of fluid velocity in the domain. The Boussinesq approximation was also employed in the momentum equation because of the small temperature gradient. Thus, the governing equations were derived based on these assumptions and are as follows neglecting Viscous dissipation [72]:

$$
\begin{gathered}
\frac{\partial \rho}{\partial t}+\nabla \cdot \rho \vec{V}=0 \\
\rho \frac{\partial \vec{V}}{\partial t}+\rho(\vec{V} \cdot \nabla) \vec{V}=-\nabla P+\mu\left(\nabla^{2} \vec{V}\right)-A_{m} \frac{(1-\lambda)^{2}}{\lambda^{3}+0.001} \vec{V}-\rho_{r e f} \beta\left(T-T_{r e f}\right) \vec{g} \\
\frac{\rho C_{p} \partial T}{\partial t}+\nabla\left(\rho C_{p} \vec{V} T\right)=-\left[\frac{\partial \rho \lambda L_{f}}{\partial t}+\nabla\left(\rho \vec{V} \lambda L_{f}\right)\right]+\nabla(k \nabla T)
\end{gathered}
$$

where $\vec{V}, T, \lambda$, and $P$ are the velocity vector, temperature, liquid volume fraction, and pressure, respectively; while $t$ is time. $T_{r e f}$ and $\rho_{\text {ref }}$ are the reference temperature and density. The third term on the right-hand side of Equation (2) represents the momentum sink for the phase change in the mushy zone [56]. The symbols $L_{f}, \rho, C_{p}, k, \mu, A_{m}$, and $\beta$ are the latent heat of fusion, density, specific heat capacity, thermal conductivity, dynamic viscosity, mushy, and volume expansion coefficient, respectively.

It is worth mentioning that the volume expansion of the PCM changing from the solid-state to the liquid-state was neglected, and the mushy zone constant was considered $10^{-5}$ based on the validation process and literature [71]. To simulate the flow of the water in the inner tube, the governing equations were the same as the above equations, ignoring the additional source of body forces and phase change. The liquid fraction, $\lambda$, is introduced as per Equation (4) [73]:

$$
\lambda=\frac{\Delta H}{L_{f}}=\left\{\begin{array}{cl}
0 & \text { if } T \leq T_{S} \\
\frac{\left(T-T_{S}\right)}{\left(T_{L}-T_{S}\right)} & \text { if } T_{S}<T<T_{L} \\
1 & \text { if } T \geq T_{L}
\end{array}\right\},
$$

where the subscripts $S$ and $L$ denote the solidus and liquidus states of PCM, and $\Delta H$ is the enthalpy variation during the phase change. The solidification or discharging rate $\dot{Q}$ is introduced as per Equation (5) [53]:

$$
\dot{Q}=\frac{Q}{t_{m}}=\frac{m\left(\int_{S} C_{p} d T+L_{f}+\int_{L} C_{p} d T\right)}{t_{m}},
$$


where $t_{m}$ is the melting time and $\mathrm{m}$ is the mass of PCM. The total enthalpy $(H)$ is achieved as per Equation (6):

$$
H=\Delta H+h
$$

where,

$$
h=\int_{T_{r e f}}^{T} C_{p} d T+h_{r e f} .
$$

A detailed description of the mathematical model can be found in the author's previous work [71].

\section{Numerical Process}

ANSYS computational fluid dynamic software (FLUENT) was employed to solve the problem using the SIMPLE algorithm for the pressure-velocity coupling scheme. The QUICK scheme was used to discretise the terms of the derivatives in the momentum and energy equations, while the PRESTO scheme was used for the continuity equation. For different equations governed, $10^{-6}$ was used as the convergence criteria. The grid independence analysis was performed before the main simulations considering different mesh and time-step sizes to determine the results independent from the grid number and the time step size. The grid independence test was performed using different cell numbers of 2,302,000,2,357,000, and 2,451,000 for the case with six twisted fins shown in Figure 1c. The melting time was considered as the criteria to find the mesh independent from the number of cells. The melting time for the system with different cell numbers of 2,302,000, $2,357,000$, and 2,451,000 are 2004, 2083, and 2098 s, respectively. The results showed that for the case of twisted f0.33inned triple-tube with six fins, 2,357,000 cells were enough to have independent results from the number of grids tested. The difference between the melting times for the cases with 2,357,000 and 2,451,000 cells is less than $0.3 \%$. Different time step sizes of $0.1,0.2$, and $0.4 \mathrm{~s}$ are studied to find the results independent from the size of the time step. The results showed similar melting times for different sizes of time step, and therefore, the size of the time step was also selected equal to $0.2 \mathrm{~s}$. The configuration of the final mesh is shown in Figure 2.
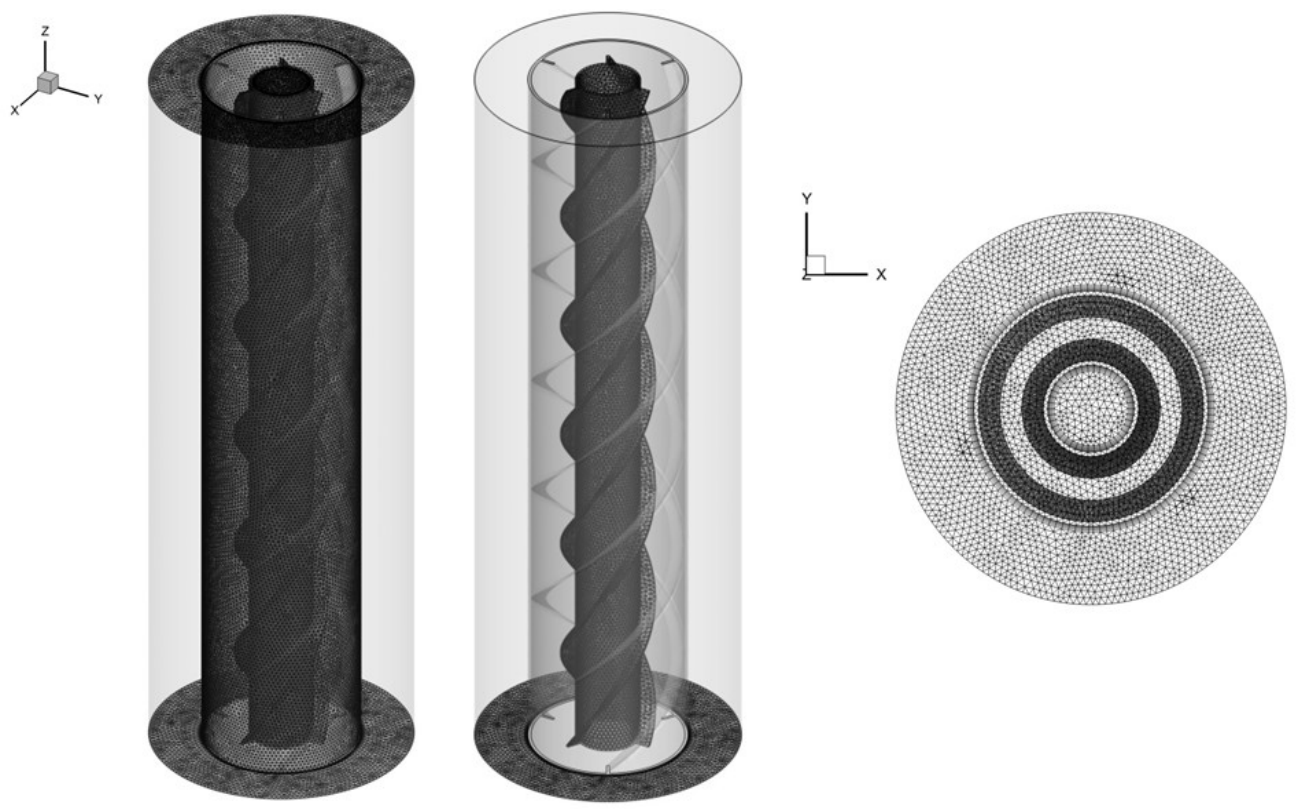

Figure 2. The configuration of the mesh after grid independence analysis.

The numerical model is verified using the experimental and numerical results of Mat et al. [60], where the effect of fins attached to both outer and inner surfaces of the tubes in the PCM zone (RT58) in a double-tube LHSHE unit was studied. In this study, constant wall 
temperature was implemented for the walls of the heat exchanger. As seen from Figure 3, the presented results are in line with the experimental data as well as numerical results for the temperature and numerical data for the melt fraction of Mat et al. [60]. It should be noted that the study of Mat et el. has been used in various studies in the literature to validate different codes.

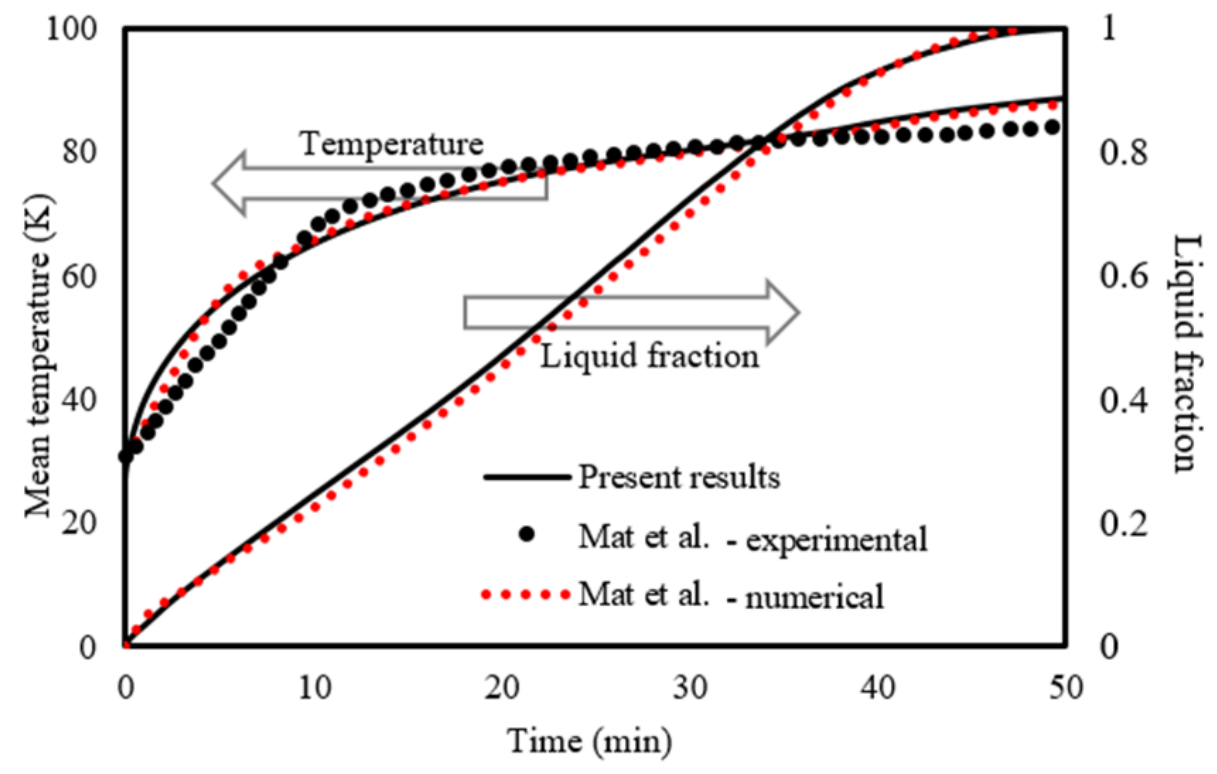

Figure 3. Verification of the numerical model.

\section{Results and Discussion}

Several simulation tests have been conducted in order to assess the potential of twisted fins on intensifying the solidification rate of paraffin (RT35) in the vertical TES triple-tube system. Three cases with no fins, straight fins, and twisted fins, are dealt with in this study. There are two, four, and six fins involved in the case of twisted fins. The total mass of PCM is fixed at $0.335 \mathrm{~kg}$, which is equal to the mass of the PCM in the case without any fins, in all of these cases to enable making meaningful performance comparisons. It should be noted that including a denser material of the enhancer (fins) does help faster rates of solidification but also impact the mass/volume of PCM being occupied in the TES unit. Therefore, the storage capacity of the system is negatively affected. To reveal the impact of twisted fins on the system's thermal response, the present results were studied in terms of the liquid-fraction contours, isothermal contour distribution, and temporal fluid-fraction profiles. In any of these cases, it was supposed that the scenario to achieve the total solidification started when the PCM at an initial temperature $\left(T_{\text {int }}=305 \mathrm{~K}\right)$ was above the PCM liquidus temperature $\left(T_{s}=302 \mathrm{~K}\right.$ ) while the HTF (water) circulating at a lower temperature $\left(T_{H T F}=323 \mathrm{~K}\right)$. This supports the formation of a solidifying layer next to the thermally-active walls so that the PCM molecules near the cooling walls initiate the solidifying phase earlier than the other PCM parts. Over time the layers grow progressively to intrude the entire PCM domain when additional amounts of heat are removed by the heat-transfer fluid (HTF) flowing outside. The presence of twisted or straight fins serves as an extra promoter for better heat communication between the HTF and PCM so that faster heat removal rates from the PCM are achieved, as seen in the next sections. It would be worthy to mention that achieving a faster time response for heat removal in actual TES application is a critical part to consider when designing a TES system. It indicates the TES system's ability to achieve a continuous and stable operation of the energy recovery [74]. If the system fails to timely respond to the energy discharging duties on the PCM side, this causes delays in attaining the cyclic solidification within the time limit, and consequently, a failure of the system's design becomes more probable. 


\subsection{Evolution of the Temperature Field}

Isotherm evolution for the three cases of no fins, straight fins, and twisted fins considered in this study over the three-time spans of solidification 600, 1200, and $1800 \mathrm{~s}$ are shown in Figure 4. During the initial span $(t \leq 600 \mathrm{~s})$, the isotherms of low temperatures around $290 \mathrm{~K}$ (the blue zones) seem to be the dominant group over the entire cavity in all examined cases. This is attributed to the fact that a major part of PCM is still liquid during this duration, and so, not much influence of solidification can be seen. Therefore, the isotherms seem similar between and close to the fin ligaments. During the subsequent span $(600<t \leq 1200 \mathrm{~s})$, the isotherms of high temperatures above $305 \mathrm{~K}$ (the red zones) slightly start to shrink throughout the entire domain, particularly in the cases with fins. By this time, the cooling effect of the heat-transfer fluid (HTF) on the PCM becomes more effective so that the solidifying layer increases in size to occupy the whole domain. Moreover, the existence of fins further supports the heat communication between the PCM and the HTF, as the existence of fins allows for better heat removal from the PCM domain. Comparing the cases with fins to the base case of no fins suggests a larger shrink in the layer of isotherms with high temperatures (the red zone), particularly when moving downward. This implies that there is little influencing role of convection compared to the role of conduction in the case of fins, particularly in the upper portion of the domain. During the final span ( $t \geq 1800 \mathrm{~s})$, the isotherms seem to be more uniform and consistent in shape than in previous durations, particularly in the lower portion of the domain. This would be due to the dominating role of heat conduction in this region, which helps earlier completion of the solidification process. Indeed, the existence of twisted fins further supports the role of heat conduction due to its curving structure, which limits the role of natural convection, and the relatively larger heat transfer area, which assists the overall heat transfer process.<smiles>[X]C1=C([Z])C1[Y]</smiles>

$600 \mathrm{~s}$
Temperature: No fins

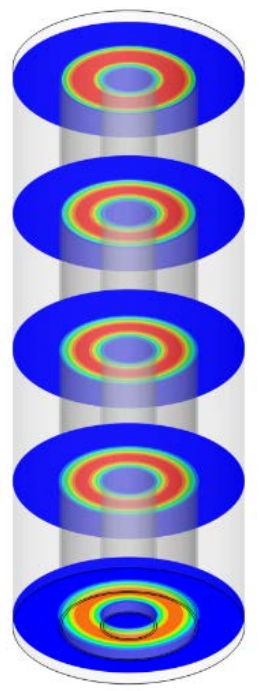

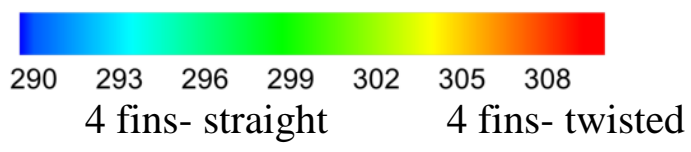

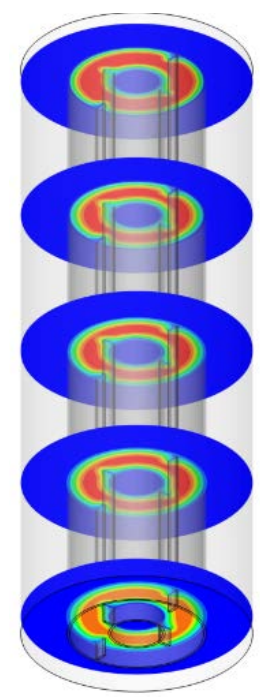

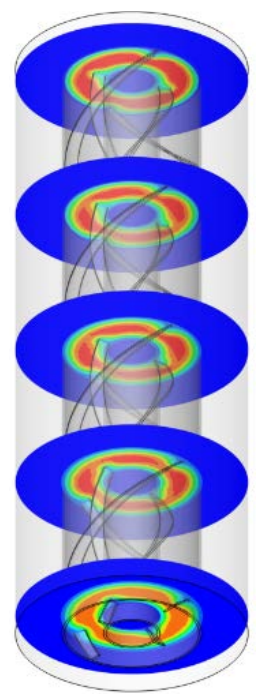

Figure 4. Cont. 

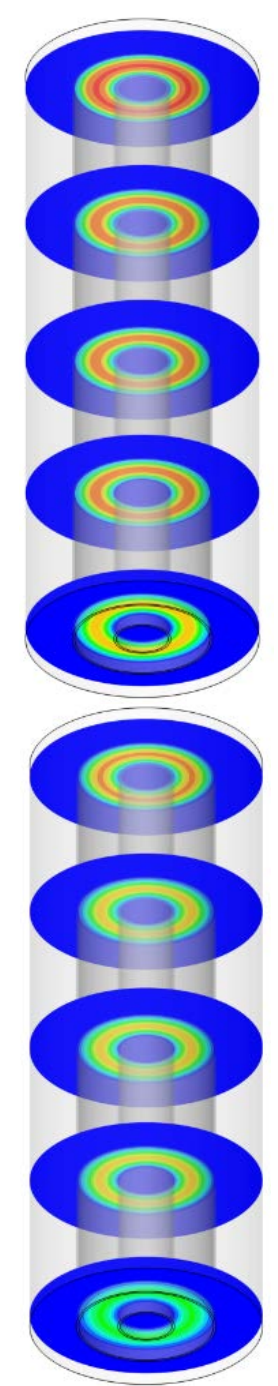
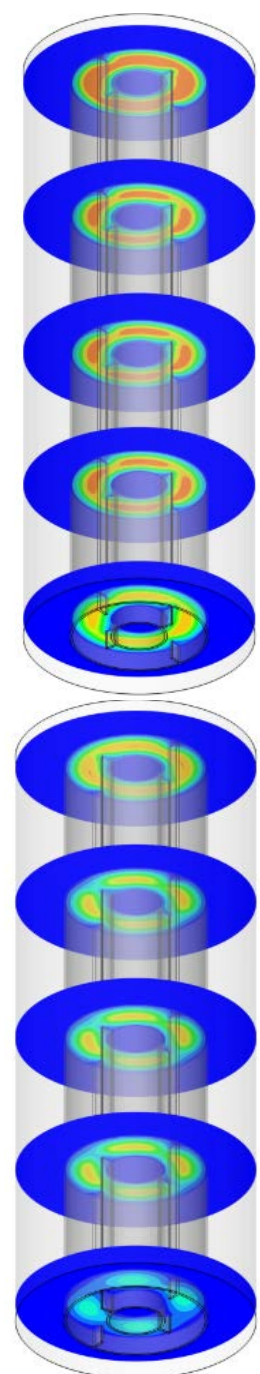
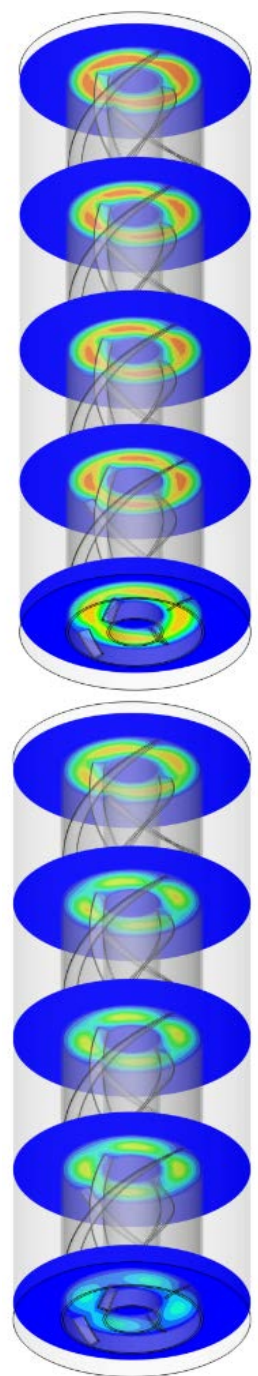

Figure 4. Evolution of temperature field for the cases of no fins, straight fins, and twisted fins at different time spans of solidification progress.

Figure 5 compares the temperature field of the cases with two, four, and six twisted fins over three different time spans of the solidification evolution. Not a big difference in the distribution of isotherms can be noticed as the number of fins increases during the early duration ( $t \leq 600 \mathrm{~s}$ ) as a major part of PCM is not yet solidified. However, as time proceeds to $t \geq 1200 \mathrm{~s}$, the size of solidifying layer increases due to the enhanced heat removal from the PCM with the existence of a higher number of fins. The effect of increasing the number of fins seems to be more noticeable in the lower portion of the domain. The movement of liquid PCM in the vertical TES units is typically governed by the dominance of gravity effect over the buoyancy effect, which after all results in a larger temperature gradient throughout the domain. This is why the PCM at the bottom within the case of six fins is early terminated solidification and appeared completely blue clearer than that in other cases, as shown in Figure $5(t=1800 \mathrm{~s})$. 


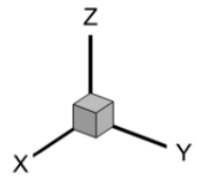

Temperature:

2 fins

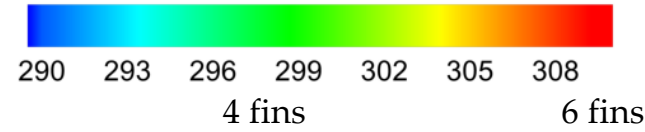

$600 \mathrm{~s}$

$1200 \mathrm{~s}$
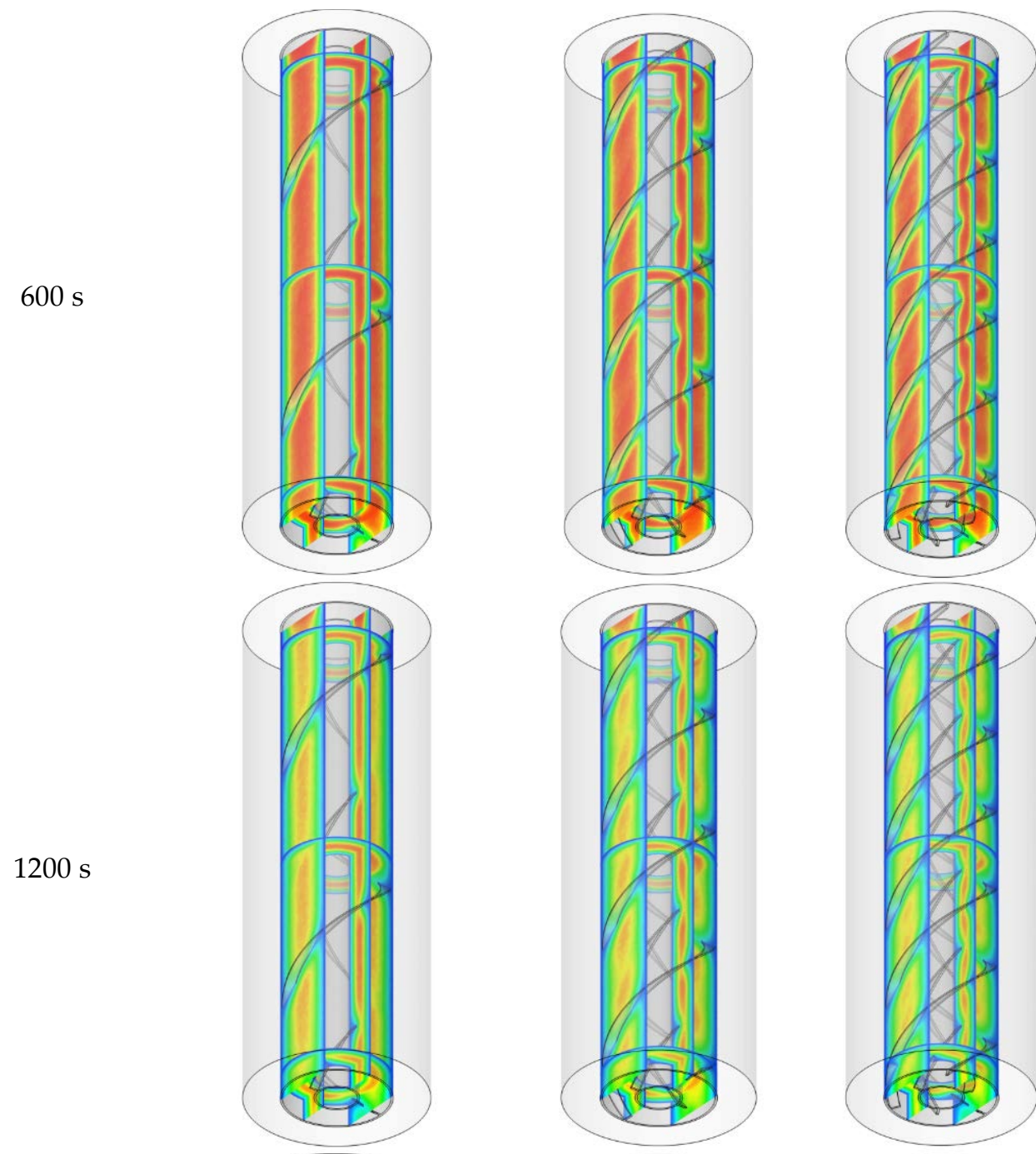

$1800 \mathrm{~s}$
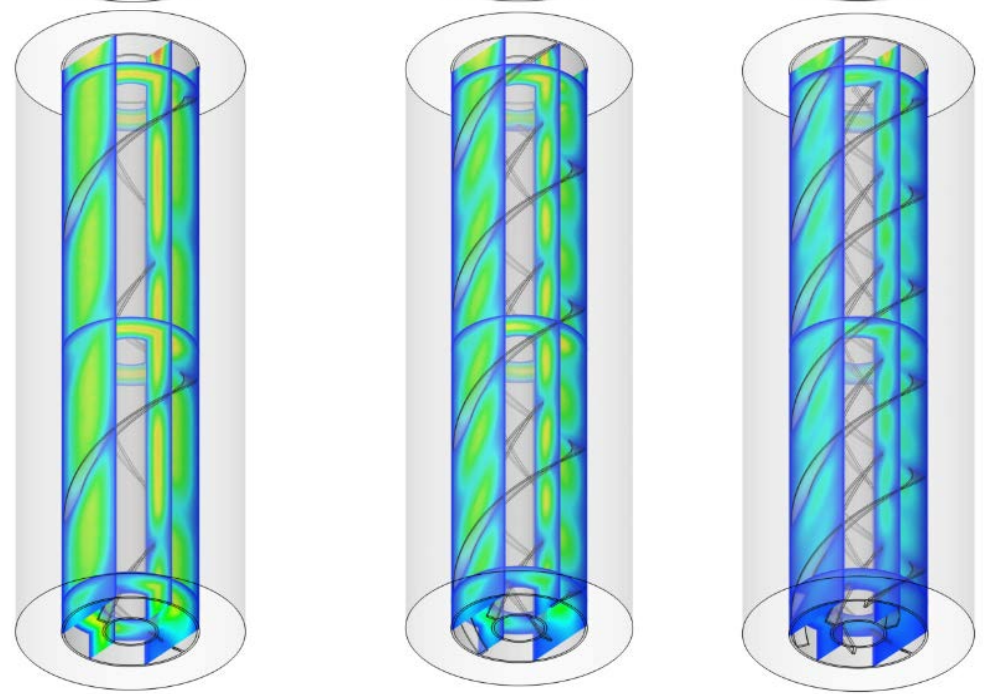

Figure 5. Evolution of temperature field for the three different cases of twisted fins at different time spans of solidification progress. 
The effects of adding straight and twisted fins on the average temperature of the PCM over different time spans are shown in Figure 6. Adding fins typically provides better heat removal from the PCM as fins work as direct passageways for heat communication between the PCM and the cooling walls. However, the data from Figure 6 indicate that applying twisted fins serves better for lowering the PCM temperature so that higher solidifying rates can be obtained. Figure 7 compares the effects of using different numbers of twisted fins on the time histories of PCM temperature during solidification mode. It can be seen that increasing the number of fins does not introduce a significant difference at the early stage (i.e., for $t \leq 500 \mathrm{~s}$ ) of solidification. However, as time progresses, the difference in the behavior curves of the average temperature becomes more noticeable as the number of fins is changed. The average temperature declines to its minimum value within a shorter time when the number of fins is doubled from two to four and six fins. Therefore, faster heat discharge rates from the PCM can be produced by increasing the number of installed twisted fins.

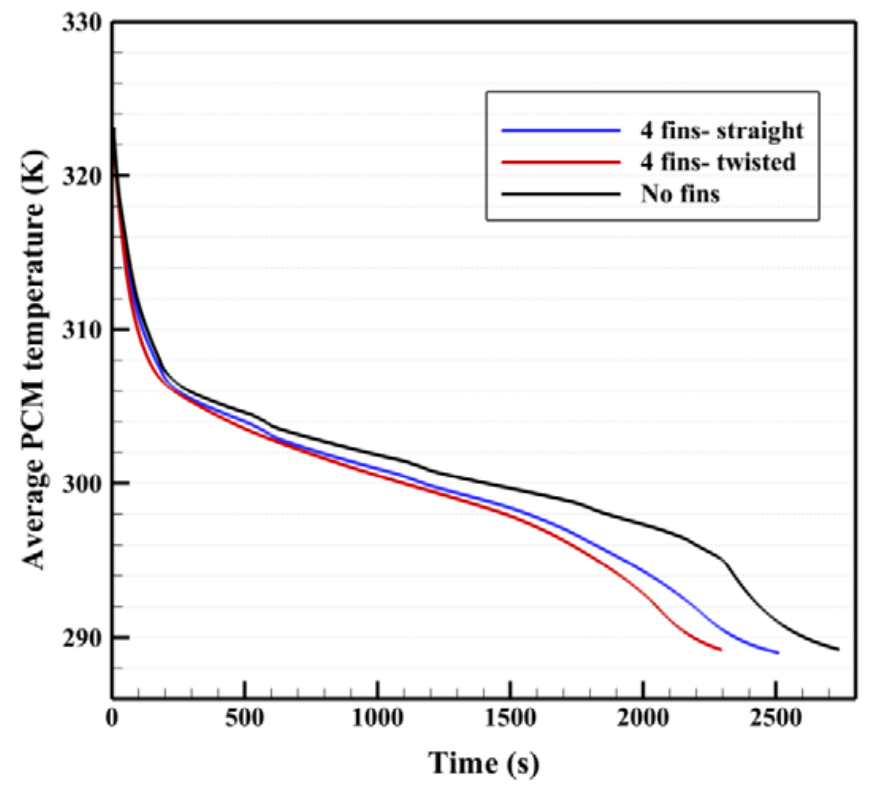

Figure 6. Time history of average temperature for the cases of no fins, straight fins, and twisted fins.

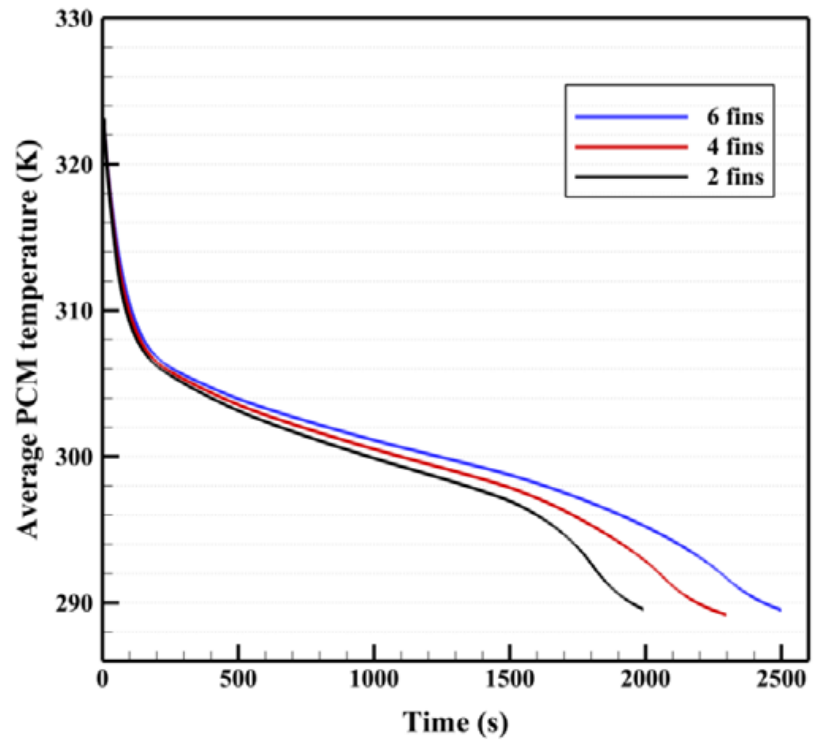

Figure 7. Time history of average temperature for the three different cases of twisted fins. 


\subsection{Evaluation of Velocity Distribution}

In addition to the significant effect of fins on the melting rate through the conduction heat transfer, twisted fins can be effective on the natural convection effect in the storage system. Figure 8 displays the z-velocity in the middle cross-section of the system for different studied cases. As shown, higher velocities can be seen in the systems with twisted fins showing the higher effect of natural convection in the domain. It should be noted that the direction of the twisted fins is along with the gravity direction which can be helpful in boosting the buoyancy effect in the domain. In other words, the twisted fins do not prevent the circulation of melted PCM in the domain due to the twisted shape of the fins.<smiles>[X]C(=[V])[Tl]</smiles>
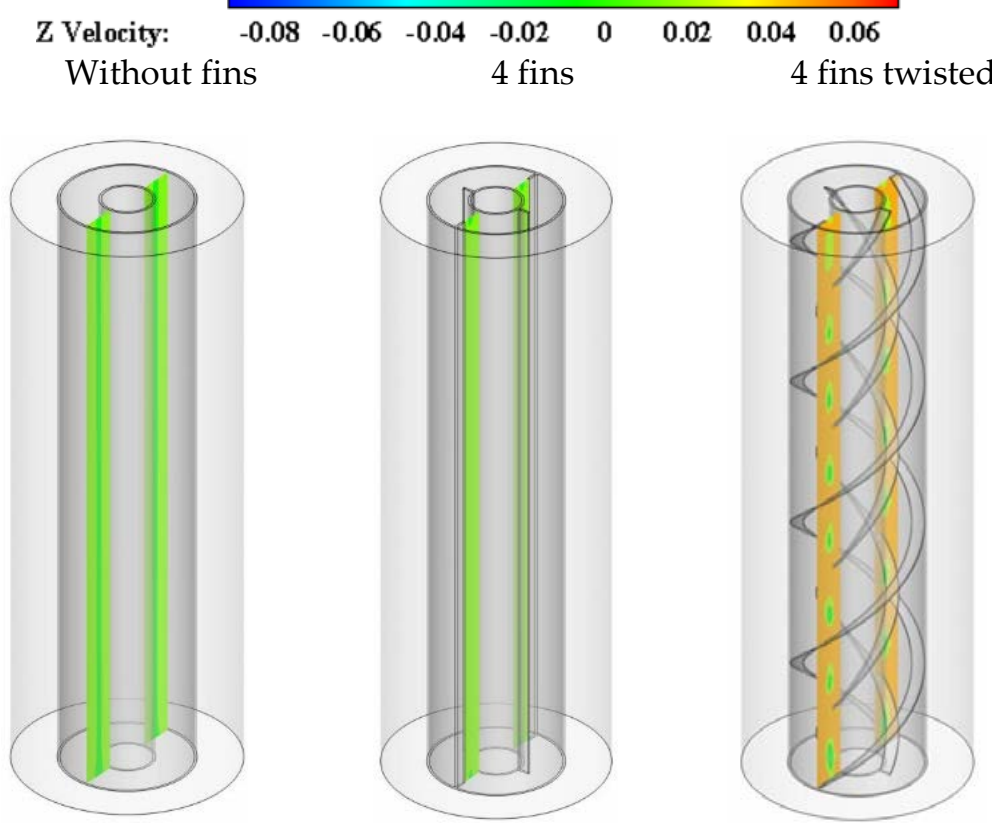

$1200 \mathrm{~s}$

2 fins
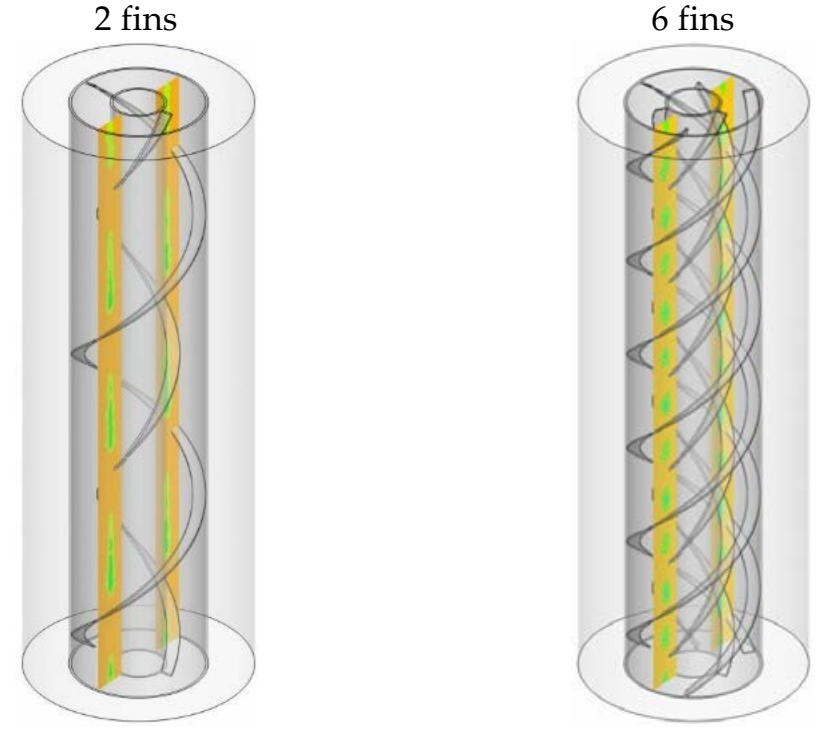

Figure 8. Evolution of z-velocity field for different studied cases at the time of $1200 \mathrm{~s}$.

\subsection{Evolution of the Liquid-Fraction Field}

The liquid-fraction contours, including the solidifying fronts (shown in light green), are illustrated in Figure 9 for the cases of no fins, straight fins, and twisted fins at five different vertical positions within time spans of 600,1200 , and $1800 \mathrm{~s}$ of solidification. During the early time $\operatorname{span}(t \leq 600 \mathrm{~s})$ and where no fins are present, the solidifying fronts 
(shown by light green) take almost the shape of uniform circles that are identical along the vertical direction. However, the addition of fins, particularly twisted fins, results in the formation of relatively bigger solidifying layers (blue areas) adjacent to and surrounding the fins, as seen in Figure 9. The fronts typically do not move away from one another because only thin solid layers can be formed during this time range. Moving to the next time span $(600<t \leq 1200 \mathrm{~s})$, the shapes of solidifying fronts get further deformed, particularly in cases when fins are present, due to the higher rates of heat removal at the cooling walls. The size of the solidifying layers (blue zones) appears to be gradually increased towards the bottom as can be seen in Figure $9(t=1200 \mathrm{~s})$. This is due to the stronger role of convection in the upper portion of the domain compared to that in the lower portion. The solidifying layer better increases in size in the case of twisted fins as the major space turns blue. In the case of twisted fins, a more important role is noticed for natural convection with more deformation in the shape of the solidifying front. The reason is that the flow-resistant forces generated due to the flow-promoting structure of twisted fins are superior compared to that in straight fins. During the last time span ( $t \geq 1800 \mathrm{~s})$, the liquid-fraction field shows fully solidified zones in the lower portion of the domain due to the minimal convection role in this part, while solidification is slightly delayed in the upper portion due to the stronger local convection. On the effects of fins, the results show that the size of the solid layer increases as the fins (twisted or straight) are added. However, the effect of twisted fins is more noticeable as the size of the solidifying layer is larger, as can be seen by comparing the liquid-fraction field between the three cases considered in Figure $9(t=1800 \mathrm{~s})$. Thus, applying twisted fins while keeping the total mass of PCM constant leads to faster evolution of solidifying frons than that when applying straight fins.<smiles>[X]C([X])[X]</smiles>

$600 \mathrm{~s}$ Liquid Fraction: No fins

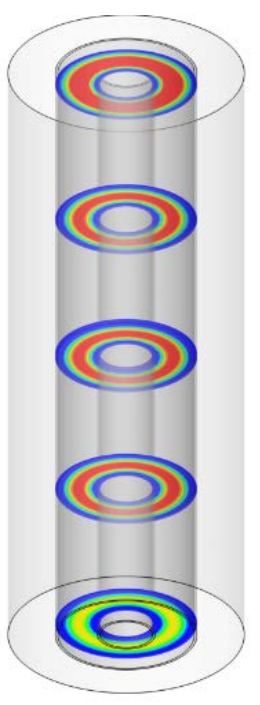

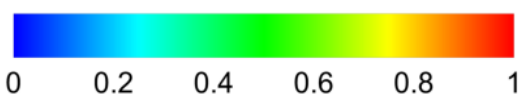

4 fins- straight

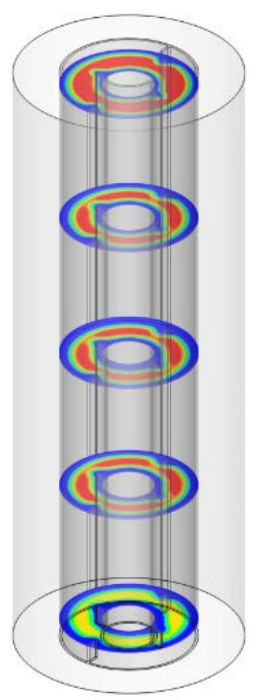

4 fins- twisted

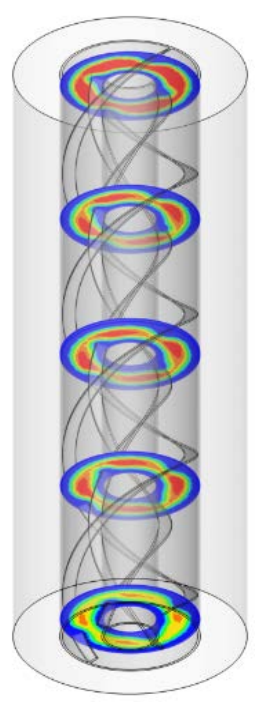

Figure 9. Cont. 
$1200 \mathrm{~s}$

$1800 \mathrm{~s}$
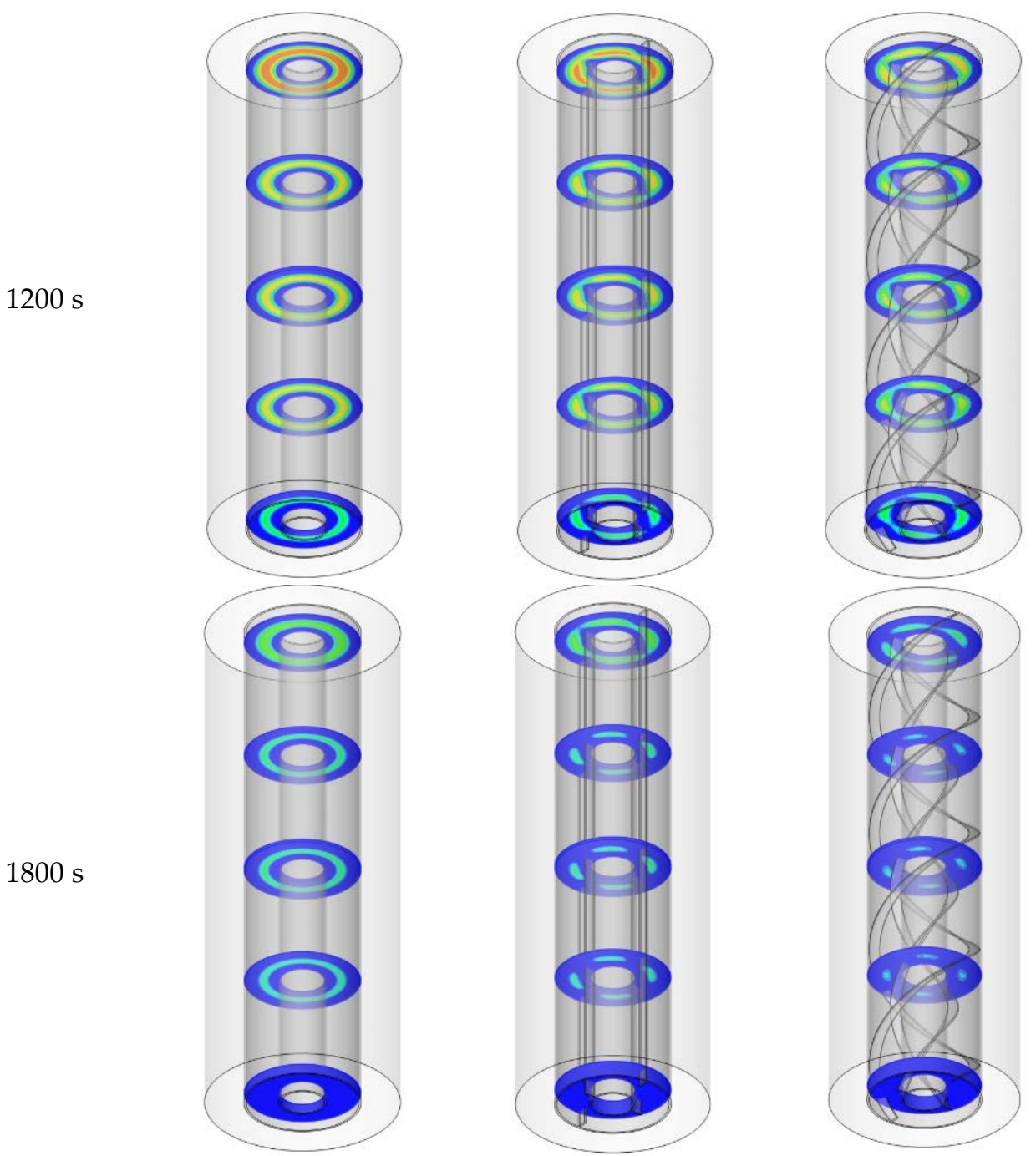

Figure 9. Evolution of liquid-fraction field for the cases of no fins, straight fins, and twisted fins at different time spans of solidification progress.

Figure 10 compares the liquid-fraction field of the cases with two, four, and six twisted fins over three different time spans of the solidification evolution. A noticeable deformation in the shape of solidifying fronts can be observed as the number of fins increases due to the enhanced heat removal from the PCM with increasing the number of fins. The size of the solidifying layers (blue zones) appears to be gradually increased towards the bottom as can be seen in Figure $10(t=1800 \mathrm{~s})$. The solidification is observed to be earlier completed in the lower parts of the vertical TES unit, indicating a strong conduction involvement in this area. A little delay occurs in all cases of twisted fins in the upper parts of the domain. The existence of fins impacts the buoyant flow of liquid PCMs in these parts so that only minor involvement of the convection is expected in the heat transfer process. Increasing the number of twisted fins from two to six greatly aids the solidification process at the upper parts of the domain. The twisted fins technically improve heat transport so that the solidifying front appears to travel quicker in two ways. First, their enormous surface area aids for superior heat transfer by conduction between the various portions of the PCM. Second, the twisted structure of fins allows for higher flow-resistant forces so that only a minor role can be played by natural convection. 
<smiles>C[In](C)C</smiles>

Liquid Fraction:
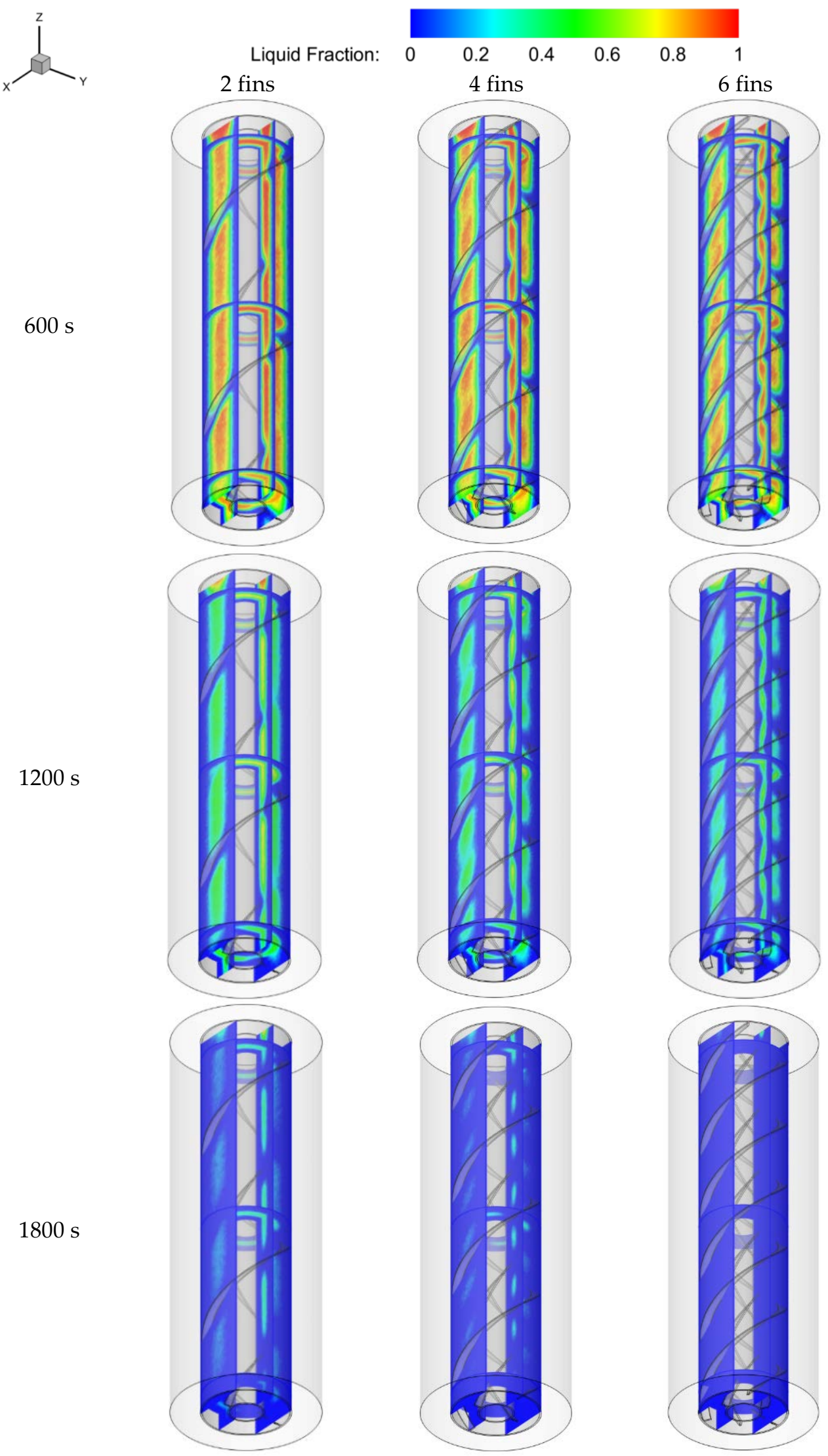

Figure 10. Evolution of liquid-fraction field for the three different cases of twisted fins at different time spans of solidification progress. 
The temporal evolution of the liquid fraction throughout the PCM solidification mode has been also tracked to better evaluate the potential of solidification enhancement when twisted fins are applied. Figure 11 compares the liquid-fraction evolution history for the three cases of no fins, straight fins, and twisted fins. The TES system in the three cases is designed to carry out the same PCM mass $(m=0.335 \mathrm{~kg})$. Data from the figure indicate that the case with twisted fins provides the best potential for solidification enhancement among the cases considered. Table 2 shows that the case with four twisted fins can reduce the solidifying time from $2739 \mathrm{~s}$ in the base case of no fins to only $2229 \mathrm{~s}$ so that a time saving of about $20 \%$ is achieved. In addition, twisted fins can cut solidifying time from $2512 \mathrm{~s}$ in the case of straight fins to $2229 \mathrm{~s}$, saving roughly $8 \%$ of the entire solidifying time. Regarding the discharge rate, data from Table 2 imply that applying twisted fins can remove heat from PCM at the rate of $34.25 \mathrm{~W}$ while applying straight fins would remove $30.45 \mathrm{~W}$ of heat compared to only $27.87 \mathrm{~W}$ in the base case of no fins. This results in an increase in the heat discharge rate of around $29 \%$ and $10 \%$, respectively, when compared to the reference case of applying no fins.

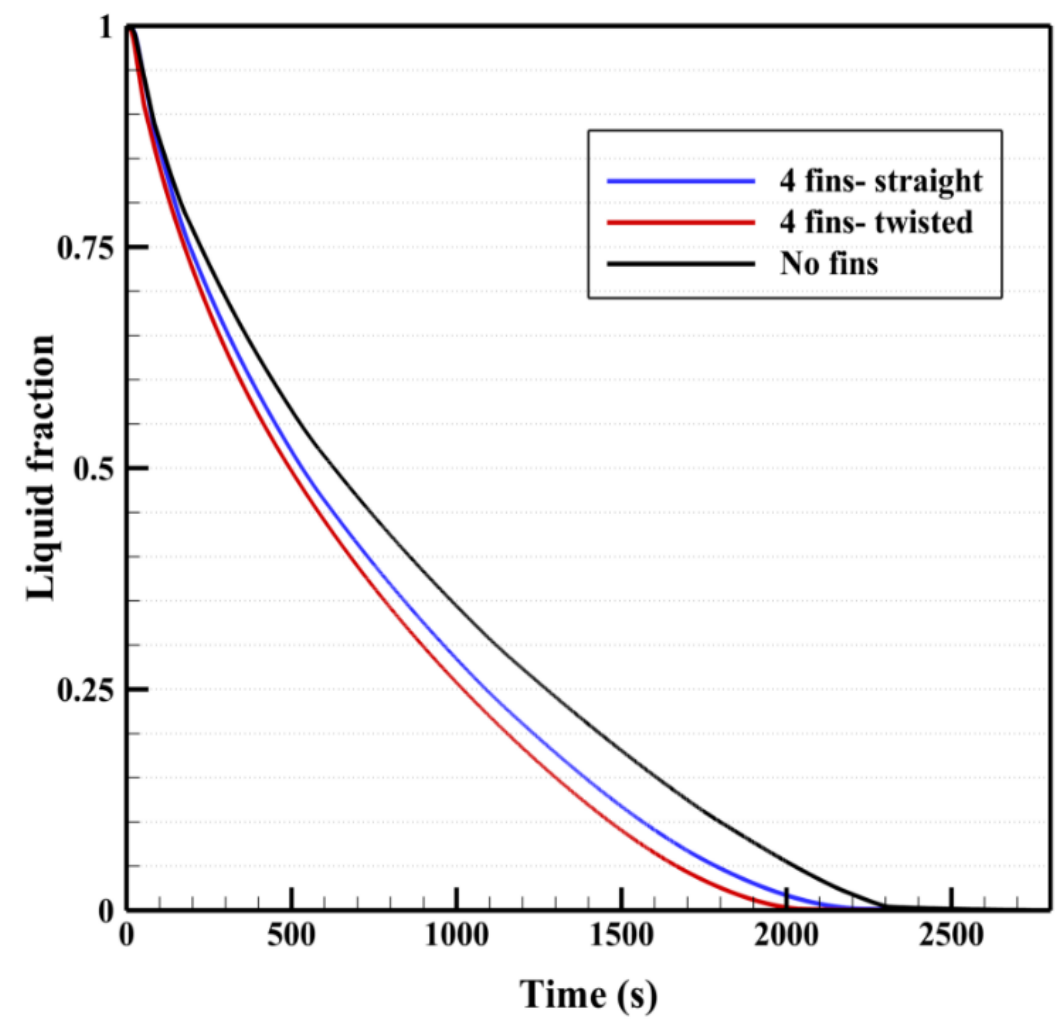

Figure 11. Temporal evolution of the PCM liquid fraction with straight and twisted fins.

Table 2. The improvement in solidifying time and discharging rate due to the inclusion of straight and twisted fins.

\begin{tabular}{ccc}
\hline Fins & Solidifying Time (s) & Discharging Rate (W) \\
\hline No fins & 2739 & 27.87 \\
Straight fins & 2512 & 30.45 \\
Four twisted fins & 2229 & 34.25 \\
\hline
\end{tabular}

The time histories for liquid-fraction evolution in the cases of two, four, and six twisted fins are compared in Figure 12. As seen in the figure, applying six twisted fins leads to the greatest possible reduction in solidifying time. Based on the data obtained for the number of fins considered, the solidifying rate generally increases as the number of twisted fins increases. The time data from Table 3 reveals that the TES system design with four and 
six twisted fins do require 2229 and $1922 \mathrm{~s}$, respectively, to reach the status of complete solidification of PCM. This implies that an 11 to $20 \%$ reduction in solidifying time is possible when doubling the number of twisted fins in use from two to four or six fins, respectively. Data from Table 3 also reveal that applying twisted fins can improve the heat discharge rate from $30.45 \mathrm{~W}$ to $34.25 \mathrm{~W}$ and $38.20 \mathrm{~W}$ when the number of twisted fins in use increases from two to four or six fins, respectively. This results in an increase in the heat discharge rate of around $13 \%$ to $26 \%$, respectively.

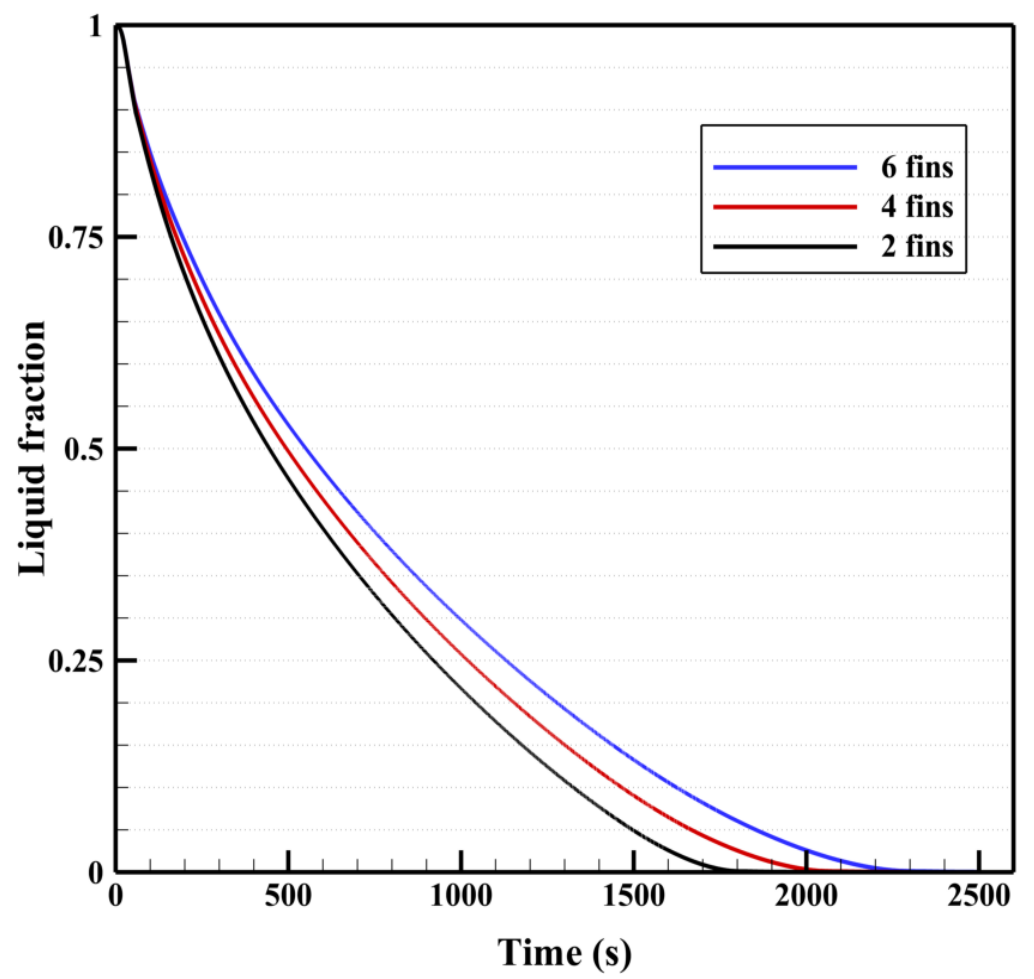

Figure 12. Temporal evolution of the PCM liquid fraction with different numbers of twisted fins.

Table 3. The improvement in solidifying time and discharging rate due to the inclusion of different twisted fins.

\begin{tabular}{ccc}
\hline Fins & Solidifying Time (s) & Discharging Rate (W) \\
\hline 2 fins & 2502 & 30.45 \\
4 fins & 2229 & 34.25 \\
6 fins & 1992 & 38.20 \\
\hline
\end{tabular}

To have a non-dimensional analysis, the dimension less time is defined as follows:

$$
\tau=\frac{t \alpha}{D}
$$

where $D$ is the hydraulic diameter of the PCM container equals $0.02 \mathrm{~m}$. It should be noted that the mass of the PCM is considered constant in all the studied cases. Table 4 presents the dimensionless solidification time for different studied cases. The use of six fins results in the lower non-dimensional solidification time which is almost $27.3 \%$ less than that for the case without fins.

Table 4. Dimensionless solidification time for different studied cases.

\begin{tabular}{cccccc}
\hline & No-Fins & Straight Fins & 2 Fins & 4 Fins & 6 Fins \\
\hline Dimensionless time & 0.016804 & 0.015411 & 0.01535 & 0.013675 & 0.012221 \\
\hline
\end{tabular}




\subsection{Impact of HTF Reynolds Number on Solidification of a PCM with Twisted Fins}

Different flow rates of the HTF that are corresponding to Reynolds number values of 500,1000 , and 1500 are examined in terms of liquid-fraction profile and average temperature profile in Figure 13a,b, respectively. The data from Figure 13a indicate that a shorter solidifying time is needed when a higher Reynolds number of the HTF are used. This is due to the fact that higher Reynolds numbers inspire a greater convective heat transfer coefficient at the thermally-active walls so that greater heat removal rates from the PCM are achieved during solidification. The corresponding data in Figure 13b show that almost lower values of the average PCM temperature can be recorded when higher Reynolds numbers of the HTF are used. This also implies that a better cooling effect can be done on the PCM side when HTF with a higher Reynolds number is used. The PCM with twisted fins takes around $2100 \mathrm{~s}$ to complete the solidification at $\mathrm{Re}=500$, but only 1980 and $1850 \mathrm{~s}$ at $\operatorname{Re}=1000$ and 1500, respectively. Therefore, when the HTF Reynolds number is increased from 500 to 1000 and 1500, the total solidification time can be saved by around $5 \%$ and $12 \%$, respectively.

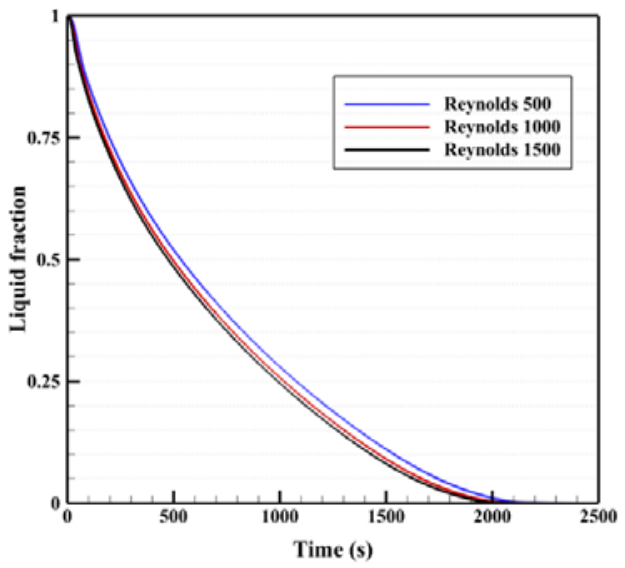

(a)

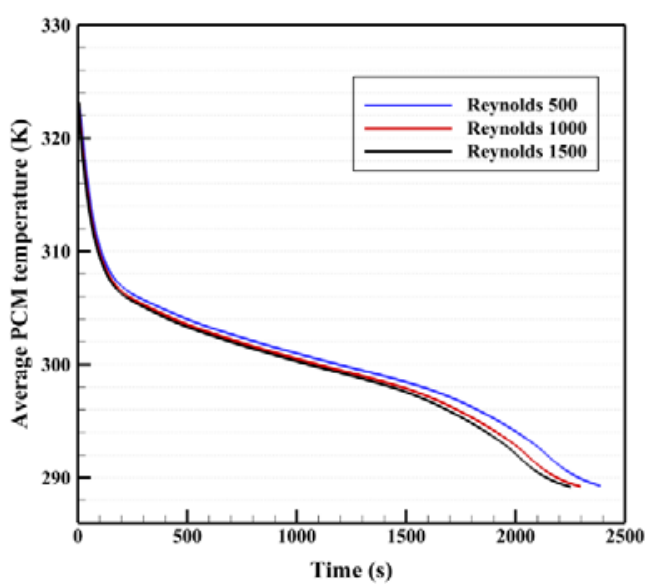

(b)

Figure 13. Evolution of the PCM liquid-fraction and average temperature profiles at three different Reynolds numbers of the HTF. (a) Liquid-fraction profile, (b) Average PCM temperature profile.

\subsection{Impact of HTF Temperature on Solidification of a PCM with Twisted Fins}

Figure 14 shows the impact of varying the HTF temperature on the time-wise evolution of the PCM liquid fraction and average temperature, respectively for $T_{H T F}=10,15$, and $20^{\circ} \mathrm{C}$. As can be seen in this figure the values of liquid fraction and average PCM temperature decreases as the HTF temperature increases. In other words, lowering the HTF temperature promotes a greater cooling impact on the PCM side. This is basically due to the fact that utilising a cooler HTF allows for a quicker solidification rate of PCM. This trend appears to be increasingly pronounced as the process approaches the point of solidification completion. As explained earlier, the contribution of conduction in the heat removal process from the PCM becomes more effective and controlling within the final period ( $t \geq 1800 \mathrm{~s}$ ) of solidification. Data from the figure shows that a PCM with twisted fins takes around $2700 \mathrm{~s}$ to complete the solidification at $T_{H T F}=20$, but only 2100 and $1650 \mathrm{~s}$ at $T_{H T F}=15$ and $10^{\circ} \mathrm{C}$, respectively. Therefore, when the HTF temperature is decreased from 20 to 15 and $10{ }^{\circ} \mathrm{C}$, the total solidification time can be saved by around $28 \%$ and $40 \%$, respectively. 


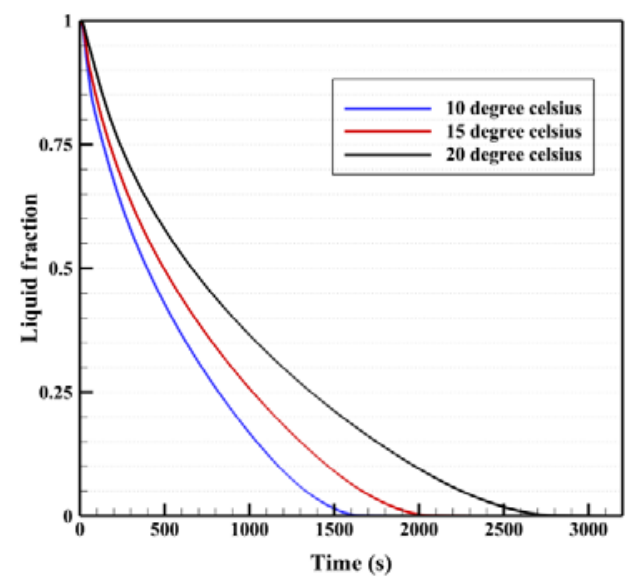

(a)

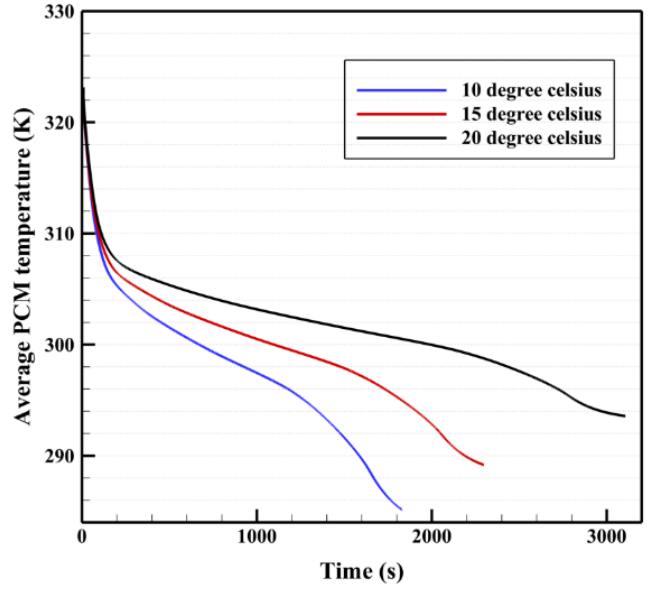

(b)

Figure 14. Evolution of PCM liquid-fraction and average temperature profiles at three different temperatures of HTF. (a) Liquid-fraction profile, (b) Average PCM temperature profile.

\section{Conclusions}

A combination of twisted fins with a triple-tube thermal energy storage system was explored and assessed in the three-dimensional modeling during the solidification process. This work involved the influence of planting the twisted fins compared with the cases of straight fins and no-fins. The effects of the inserted fins' number, inlet temperature, and the flow rate (represented with the Re) of the heat transfer fluid were evaluated. The PCM was located between the inner and the outer tubes, which include the heat transfer fluid flows in an opposite direction as the best technique for releasing heat from the PCM. The performance of the unit was evaluated by analysing the reduction of the liquid fraction and the thermal profile, as well as the solidification time and discharge rate. The outcomes specify the benefits of combining the twisted fins with the TES. The results reveal that the utilizing of four twisted fins reduced the solidification time by $12.7 \%$ and $22.9 \%$ compared with four straight fins and the no-fins cases (assuming the same mass of the PCM), respectively. Likewise, applying four twisted fins enhanced the discharging rate compared with four straight fins and the no-fins. Increasing the number of fins from two to four and six, the solidification time reduces by $11.9 \%$ and $25.6 \%$, respectively. Adding fins enhances the thermal removal from the PCM as fins work as direct passageways for heat communication between the PCM and the cooling walls. The solidification rate increases with increasing the Reynolds number (Re); When the Re of the HTF is increased from 500 to 1000 and 1500, the solidification time is reduced by $5 \%$ and $12 \%$, respectively. Further, the solidification rate increase with decreasing the heat transfer fluid temperature; when the HTF temperature is reduced from 20 to 15 and $10{ }^{\circ} \mathrm{C}$, the discharge time decreased by $28 \%$ and $40 \%$, respectively. This work offers an innovative design for adding fins to improve the thermal efficiency of the LHTES units.

Author Contributions: Conceptualization, X.S., P.T.; methodology, X.S., P.T.; software, P.T.; validation, P.T.; formal analysis, X.S., J.M.M., H.I.M., H.S.M., W.Z. and P.T.; investigation, X.S., J.M.M., H.I.M., H.S.M., W.Z. and P.T.; resources, X.S., P.T.; writing—original draft preparation, X.S., J.M.M., H.I.M., H.S.M., W.Z. and P.T.; writing-review and editing, X.S., J.M.M., H.I.M., H.S.M., W.Z. and P.T.; visualization, X.S., W.Z. and P.T.; supervision, X.S., P.T.; All authors have read and agreed to the published version of the manuscript.

Funding: The study was supported by the Jiangsu Provincial Basic Research Program (Natural Science Fund) (Grant no. BK20191050), Natural Science Research Project of Jiangsu Province Colleges and Universities (Grant no. 18KJD560001), Philosophy and Social Science Project of Jiangsu Province Colleges and Universities (Grant no. 2019SJA1659).

Institutional Review Board Statement: Not applicable. 
Informed Consent Statement: Not applicable.

Data Availability Statement: The data will be available on request.

Conflicts of Interest: The authors declare no conflict of interest.

\section{Nomenclature}

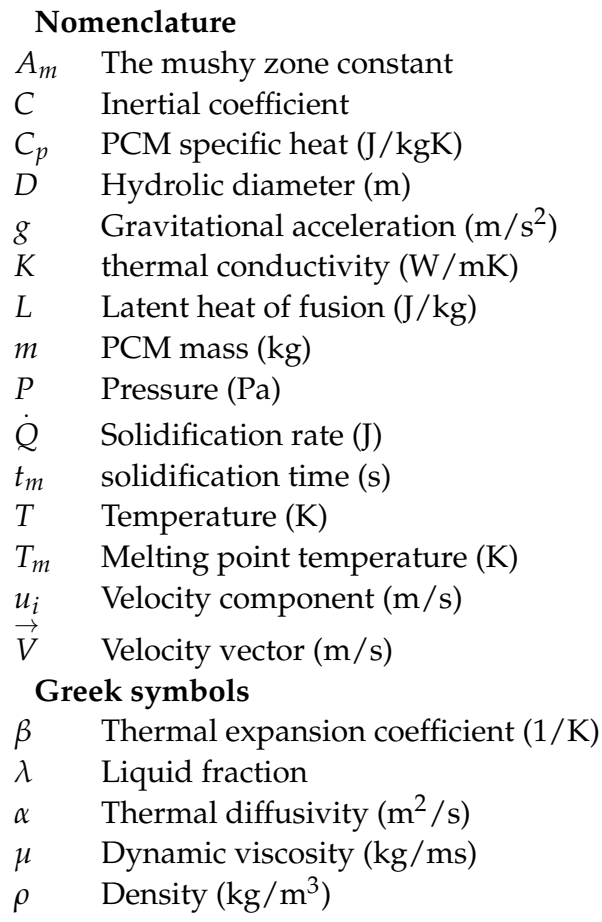

\section{References}

1. Wu, W.-F.; Liu, N.; Cheng, W.-L.; Liu, Y. Study on the effect of shape-stabilized phase change materials on spacecraft thermal control in extreme thermal environment. Energy Convers. Manag. 2013, 69, 174-180. [CrossRef]

2. Guo, X.; Liu, J.; Dai, L.; Liu, Q.; Fang, D.; Wei, A.; Wang, J. Friction-wear failure mechanism of tubing strings used in high-pressure, high-temperature and high-yield gas wells. Wear 2021, 468, 203576. [CrossRef]

3. Zhao, X.; Gu, B.; Gao, F.; Chen, S. Matching model of energy supply and demand of the integrated energy system in coastal areas. J. Coast. Res. 2020, 103, 983-989. [CrossRef]

4. Mohammed, H.I.; Giddings, D.; Walker, G.S. CFD multiphase modelling of the acetone condensation and evaporation process in a horizontal circular tube. Int. J. Heat Mass Transf. 2019, 134, 1159-1170. [CrossRef]

5. Zhang, L.; Zheng, H.; Wan, T.; Shi, D.; Lyu, L.; Cai, G. An integrated control algorithm of power distribution for islanded microgrid based on improved virtual synchronous generator. IET Renew. Power Gener. 2021, 15, 2674-2685. [CrossRef]

6. Du, X.; Li, J.; Niu, G.; Yuan, J.-H.; Xue, K.-H.; Xia, M.; Pan, W.; Yang, X.; Zhu, B.; Tang, J. Lead halide perovskite for efficient optoacoustic conversion and application toward high-resolution ultrasound imaging. Nat. Commun. 2021, 12, 3348. [CrossRef]

7. Dai, Z.; Xie, J.; Chen, Z.; Zhou, S.; Liu, J.; Liu, W.; Xi, Z.; Ren, X. Improved energy storage density and efficiency of (1-x) $\mathrm{Ba}_{0.85} \mathrm{Ca}_{0.15} \mathrm{Zr}_{0.1} \mathrm{Ti}_{0.9} \mathrm{O}_{3}-\mathrm{XBiMg}_{2 / 3} \mathrm{Nb}_{1 / 3} \mathrm{O}_{3}$ lead-free ceramics. Chem. Eng. J. 2021, 410, 128341. [CrossRef]

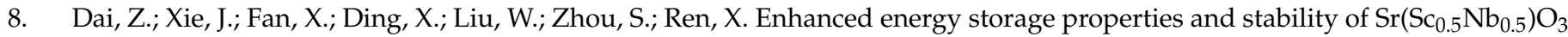
modified $0.65 \mathrm{BaTiO}_{3}-0.35 \mathrm{Bi}_{0.5} \mathrm{Na}_{0.5} \mathrm{TiO}_{3}$ ceramics. Chem. Eng. J. 2020, 397, 125520. [CrossRef]

9. Ghalambaz, M.; Mohammed, H.I.; Mahdi, J.M.; Eisapour, A.H.; Younis, O.; Ghosh, A.; Talebizadehsardari, P.; Yaïci, W. Intensifying the Charging Response of a Phase-Change Material with Twisted Fin Arrays in a Shell-And-Tube Storage System. Energies 2021, 14, 1619. [CrossRef]

10. Yang, X.; Guo, J.; Yang, B.; Cheng, H.; Wei, P.; He, Y.-L. Design of non-uniformly distributed annular fins for a shell-and-tube thermal energy storage unit. Appl. Energy 2020, 279, 115772. [CrossRef]

11. Zhang, B.; Xu, D.; Liu, Y.; Li, F.; Cai, J.; Du, L. Multi-scale evapotranspiration of summer maize and the controlling meteorological factors in north China. Agric. For. Meteorol. 2016, 216, 1-12. [CrossRef]

12. Berardi, U.; Soudian, S. Benefits of latent thermal energy storage in the retrofit of Canadian high-rise residential buildings. Build. Simul. 2018, 11, 709-723. [CrossRef]

13. Sun, L.; Li, C.; Zhang, C.; Su, Z.; Chen, C. Early monitoring of rebar corrosion evolution based on FBG sensor. Int. J. Struct. Stab. Dyn. 2018, 18, 1840001. [CrossRef] 
14. Mahdi, J.M.; Mohammed, H.I.; Talebizadehsardari, P. A new approach for employing multiple PCMs in the passive thermal management of photovoltaic modules. Sol. Energy 2021, 222, 160-174. [CrossRef]

15. Qureshi, Z.A.; Ali, H.M.; Khushnood, S. Recent advances on thermal conductivity enhancement of phase change materials for energy storage system: A review. Int. J. Heat Mass Transf. 2018, 127, 838-856. [CrossRef]

16. Yang, X.; Wei, P.; Wang, X.; He, Y.-L. Gradient design of pore parameters on the melting process in a thermal energy storage unit filled with open-cell metal foam. Appl. Energy 2020, 268, 115019. [CrossRef]

17. Xu, Q.; Wang, K.; Zou, Z.; Zhong, L.; Akkurt, N.; Feng, J.; Xiong, Y.; Han, J.; Wang, J.; Du, Y. A new type of two-supply, one-return, triple pipe-structured heat loss model based on a low temperature district heating system. Energy 2021, 218, 119569. [CrossRef]

18. Mehryan, S.A.M.; Ghalambaz, M.; Sasani Gargari, L.; Hajjar, A.; Sheremet, M. Natural convection flow of a suspension containing nano-encapsulated phase change particles in an eccentric annulus. J. Energy Storage 2020, 28, 101236. [CrossRef]

19. Abdulateef, A.M.; Abdulateef, J.; Al-Abidi, A.A.; Sopian, K.; Mat, S.; Mahdi, M.S. A combination of fins-nanoparticle for enhancing the discharging of phase-change material used for liquid desiccant air conditioning unite. J. Energy Storage 2019, 24, 100784. [CrossRef]

20. Mahani, R.B.; Mohammed, H.I.; Mahdi, J.M.; Alamshahi, F.; Ghalambaz, M.; Talebizadehsardari, P.; Yaïci, W. Phase Change Process in a Zigzag Plate Latent Heat Storage System during Melting and Solidification. Molecules 2020, 25, 4643. [CrossRef]

21. Shanan, Z.J.; Hadi, S.M.; Shanshool, S.K. Structural Analysis of Chemical and Green Synthesis of CuO Nanoparticles and their Effect on Biofilm Formation. Baghdad Sci. J. 2018, 15, 0211. [CrossRef]

22. Mahdi, J.M.; Nsofor, E.C. Solidification of a PCM with nanoparticles in triplex-tube thermal energy storage system. Appl. Therm. Eng. 2016, 108, 596-604. [CrossRef]

23. Al-Jethelah, M.; Tasnim, S.H.; Mahmud, S.; Dutta, A. Nano-PCM filled energy storage system for solar-thermal applications. Renew. Energy 2018, 126, 137-155. [CrossRef]

24. Liao, Z.; Xu, C.; Ren, Y.; Gao, F.; Ju, X.; Du, X. A novel effective thermal conductivity correlation of the PCM melting in spherical PCM encapsulation for the packed bed TES system. Appl. Therm. Eng. 2018, 135, 116-122. [CrossRef]

25. Mahdi, J.M.; Mohammed, H.I.; Hashim, E.T.; Talebizadehsardari, P.; Nsofor, E.C. Solidification enhancement with multiple PCMs, cascaded metal foam and nanoparticles in the shell-and-tube energy storage system. Appl. Energy 2020, 257, 113993. [CrossRef]

26. Eisapour, M.; Eisapour, A.H.; Hosseini, M.J.; Talebizadehsardari, P. Exergy and energy analysis of wavy tubes photovoltaicthermal systems using microencapsulated PCM nano-slurry coolant fluid. Appl. Energy 2020, 266, 114849. [CrossRef]

27. Ghalambaz, M.; Mehryan, S.; Hajjar, A.; Veismoradi, A. Unsteady natural convection flow of a suspension comprising NanoEncapsulated Phase Change Materials (NEPCMs) in a porous medium. Adv. Powder Technol. 2020, 31, 954-966. [CrossRef]

28. Talebizadeh Sardari, P.; Mohammed, H.I.; Mahdi, J.M.; Ghalambaz, M.; Gillott, M.; Walker, G.S.; Grant, D.; Giddings, D. Localized heating element distribution in composite metal foam-phase change material: Fourier's law and creeping flow effects. Int. J. Energy Res. 2021, 45, 13380-13396. [CrossRef]

29. Ghalambaz, M.; Mohammed, H.I.; Naghizadeh, A.; Islam, M.S.; Younis, O.; Mahdi, J.M.; Chatroudi, I.S.; Talebizadehsardari, P. Optimum Placement of Heating Tubes in a Multi-Tube Latent Heat Thermal Energy Storage. Materials 2021, 14, 1232. [CrossRef]

30. Talebizadehsardari, P.; Mohammed, H.I.; Mahdi, J.M.; Gillott, M.; Walker, G.S.; Grant, D.; Giddings, D. Effect of airflow channel arrangement on the discharge of a composite metal foam-phase change material heat exchanger. Int. J. Energy Res. 2021, 45, 2593-2609. [CrossRef]

31. Ju, Y.; Zhu, T.; Mashayekhi, R.; Mohammed, H.I.; Khan, A.; Talebizadehsardari, P.; Yaïci, W. Evaluation of Multiple Semi-Twisted Tape Inserts in a Heat Exchanger Pipe Using $\mathrm{Al}_{2} \mathrm{O}_{3}$ Nanofluid. Nanomaterials 2021, 11, 1570. [CrossRef]

32. Mahdi, J.M.; Nsofor, E.C. Melting enhancement in triplex-tube latent thermal energy storage system using nanoparticles-fins combination. Int. J. Heat Mass Transf. 2017, 109, 417-427. [CrossRef]

33. Sheikholeslami, M.; Lohrasbi, S.; Ganji, D.D. Numerical analysis of discharging process acceleration in LHTESS by immersing innovative fin configuration using finite element method. Appl. Therm. Eng. 2016, 107, 154-166. [CrossRef]

34. Mohammed, H.I.; Talebizadehsardari, P.; Mahdi, J.M.; Arshad, A.; Sciacovelli, A.; Giddings, D. Improved melting of latent heat storage via porous medium and uniform Joule heat generation. J. Energy Storage 2020, 31, 101747. [CrossRef]

35. Dai, Z.; Guo, S.; Gong, Y.; Wang, Z. Semiconductor flexoelectricity in graphite-doped $\mathrm{SrTiO}_{3}$ ceramics. Ceram. Int. 2021, 47, 6535-6539. [CrossRef]

36. Sun, J.; Aslani, F.; Wei, J.; Wang, X. Electromagnetic absorption of copper fiber oriented composite using 3D printing. Constr. Build. Mater. 2021, 300, 124026. [CrossRef]

37. Ghalambaz, M.; Zadeh, S.M.H.; Mehryan, S.; Pop, I.; Wen, D. Analysis of melting behavior of PCMs in a cavity subject to a non-uniform magnetic field using a moving grid technique. Appl. Math. Model. 2020, 77, 1936-1953. [CrossRef]

38. Ghalambaz, M.; Zadeh, S.M.H.; Mehryan, S.; Ayoubloo, K.A.; Sedaghatizadeh, N. Non-Newtonian behavior of an electrical and magnetizable phase change material in a filled enclosure in the presence of a non-uniform magnetic field. Int. Commun. Heat Mass Transf. 2020, 110, 104437. [CrossRef]

39. Jiang, T.; Liu, Z.; Wang, G.; Chen, Z. Comparative study of thermally stratified tank using different heat transfer materials for concentrated solar power plant. Energy Rep. 2021, 7, 3678-3687. [CrossRef]

40. Tao, L.C. Generalized numerical solutions of freezing a saturated liquid in cylinders and spheres. AIChE J. 1967, 13, 165-169. [CrossRef] 
41. Gortych, M.; Lipnicki, Z.; Weigand, B. An experimental and theoretical study of the solidification process of phase change materials in a horizontal annular enclosure. Appl. Therm. Eng. 2019, 161, 114140. [CrossRef]

42. Abdollahzadeh, M.; Esmaeilpour, M. Enhancement of phase change material (PCM) based latent heat storage system with nano fluid and wavy surface. Int. J. Heat Mass Transf. 2015, 80, 376-385. [CrossRef]

43. Shahsavar, A.; Al-Rashed, A.A.A.A.; Entezari, S.; Sardari, P.T. Melting and solidification characteristics of a double-pipe latent heat storage system with sinusoidal wavy channels embedded in a porous medium. Energy 2019, 171, 751-769. [CrossRef]

44. Choi, J.C.; Kim, S.D. Heat-transfer characteristics of a latent heat storage system using $\mathrm{MgCl}_{2} \cdot 6 \mathrm{H}_{2} \mathrm{O}$. Energy 1992, $17,1153-1164$. [CrossRef]

45. Wang, P.; Li, D.; Huang, Y.; Zheng, X.; Wang, Y.; Peng, Z.; Ding, Y. Numerical Study of Solidification in a Plate Heat Exchange Device with a Zigzag Configuration Containing Multiple Phase-Change-Materials. Energies 2016, 9, 394. [CrossRef]

46. Talebizadehsardari, P.; Mahdi, J.M.; Mohammed, H.I.; Moghimi, M.A.; Hossein Eisapour, A.; Ghalambaz, M. Consecutive charging and discharging of a PCM-based plate heat exchanger with zigzag configuration. Appl. Therm. Eng. 2021, 193, 116970. [CrossRef]

47. Li, H.; Xu, B.; Lu, G.; Du, C.; Huang, N. Multi-objective optimization of PEM fuel cell by coupled significant variables recognition, surrogate models and a multi-objective genetic algorithm. Energy Convers. Manag. 2021, 236, 114063. [CrossRef]

48. Li, H.-W.; Gao, Y.-F.; Du, C.-H.; Hong, W.-P. Numerical study on swirl cooling flow, heat transfer and stress characteristics based on fluid-structure coupling method under different swirl chamber heights and Reynolds numbers. Int. J. Heat Mass Transf. 2021, 173, 121228. [CrossRef]

49. Shokouhmand, H.; Kamkari, B. Numerical Simulation of Phase Change Thermal Storage in Finned Double-Pipe Heat Exchanger. Appl. Mech. Mater. 2012, 232, 742-746. [CrossRef]

50. Bazai, H.; Moghimi, M.A.; Mohammed, H.I.; Babaei-Mahani, R.; Talebizadehsardari, P. Numerical study of circular-elliptical double-pipe thermal energy storage systems. J. Energy Storage 2020, 30, 101440. [CrossRef]

51. Shahsavar, A.; Ali, H.M.; Mahani, R.B.; Talebizadehsardari, P. Numerical study of melting and solidification in a wavy double-pipe latent heat thermal energy storage system. J. Therm. Anal. Calorim. 2020, 141, 1785-1799. [CrossRef]

52. Shahsavar, A.; Khosravi, J.; Mohammed, H.I.; Talebizadehsardari, P. Performance evaluation of melting/solidification mechanism in a variable wave-length wavy channel double-tube latent heat storage system. J. Energy Storage 2020, 27, 101063. [CrossRef]

53. Xu, Y.; Ren, Q.; Zheng, Z.-J.; He, Y.-L. Evaluation and optimization of melting performance for a latent heat thermal energy storage unit partially filled with porous media. Appl. Energy 2017, 193, 84-95. [CrossRef]

54. Xu, Y.; Li, M.-J.; Zheng, Z.-J.; Xue, X.-D. Melting performance enhancement of phase change material by a limited amount of metal foam: Configurational optimization and economic assessment. Appl. Energy 2018, 212, 868-880. [CrossRef]

55. Ghalambaz, M.; Mahdi, J.M.; Shafaghat, A.; Eisapour, A.H.; Younis, O.; Talebizadeh Sardari, P.; Yaïci, W. Effect of Twisted Fin Array in a Triple-Tube Latent Heat Storage System during the Charging Mode. Sustainability 2021, 13, 2685. [CrossRef]

56. Mahdi, J.M.; Lohrasbi, S.; Ganji, D.D.; Nsofor, E.C. Accelerated melting of PCM in energy storage systems via novel configuration of fins in the triplex-tube heat exchanger. Int. J. Heat Mass Transf. 2018, 124, 663-676. [CrossRef]

57. Mahdi, J.M.; Nsofor, E.C. Melting enhancement in triplex-tube latent heat energy storage system using nanoparticles-metal foam combination. Appl. Energy 2017, 191, 22-34. [CrossRef]

58. Li, Z.; Shahsavar, A.; Al-Rashed, A.A.A.A.; Talebizadehsardari, P. Effect of porous medium and nanoparticles presences in a counter-current triple-tube composite porous/nano-PCM system. Appl. Therm. Eng. 2020, 167, 114777. [CrossRef]

59. Abdulateef, A.M.; Mat, S.; Abdulateef, J.; Sopian, K.; Al-Abidi, A.A. Geometric and design parameters of fins employed for enhancing thermal energy storage systems: A review. Renew. Sustain. Energy Rev. 2018, 82, 1620-1635. [CrossRef]

60. Mat, S.; Al-Abidi, A.A.; Sopian, K.; Sulaiman, M.Y.; Mohammad, A.T. Enhance heat transfer for PCM melting in triplex tube with internal-external fins. Energy Convers. Manag. 2013, 74, 223-236. [CrossRef]

61. Rabienataj Darzi, A.A.; Jourabian, M.; Farhadi, M. Melting and solidification of PCM enhanced by radial conductive fins and nanoparticles in cylindrical annulus. Energy Convers. Manag. 2016, 118, 253-263. [CrossRef]

62. Pizzolato, A.; Sharma, A.; Maute, K.; Sciacovelli, A.; Verda, V. Design of effective fins for fast PCM melting and solidification in shell-and-tube latent heat thermal energy storage through topology optimization. Appl. Energy 2017, 208, 210-227. [CrossRef]

63. Yıldız, Ç.; Arıcı, M.; Nižetić, S.; Shahsavar, A. Numerical investigation of natural convection behavior of molten PCM in an enclosure having rectangular and tree-like branching fins. Energy 2020, 207, 118223. [CrossRef]

64. Yu, C.; Wu, S.; Huang, Y.; Yao, F.; Liu, X. Charging performance optimization of a latent heat storage unit with fractal tree-like fins. J. Energy Storage 2020, 30, 101498. [CrossRef]

65. Rathod, M.K.; Banerjee, J. Thermal performance enhancement of shell and tube Latent Heat Storage Unit using longitudinal fins. Appl. Therm. Eng. 2015, 75, 1084-1092. [CrossRef]

66. Abdulateef, A.M.; Mat, S.; Sopian, K.; Abdulateef, J.; Gitan, A.A. Experimental and computational study of melting phase-change material in a triplex tube heat exchanger with longitudinal/triangular fins. Sol. Energy 2017, 155, 142-153. [CrossRef]

67. Shahsavar, A.; Goodarzi, A.; Mohammed, H.I.; Shirneshan, A.; Talebizadehsardari, P. Thermal performance evaluation of non-uniform fin array in a finned double-pipe latent heat storage system. Energy 2020, 193, 116800. [CrossRef]

68. Maakoul, A.E.; Laknizi, A.; Saadeddine, S.; Abdellah, A.B.; Meziane, M.; Metoui, M.E. Numerical design and investigation of heat transfer enhancement and performance for an annulus with continuous helical baffles in a double-pipe heat exchanger. Energy Convers. Manag. 2017, 133, 76-86. [CrossRef] 
69. Maakoul, A.E.; Metoui, M.E.; Abdellah, A.B.; Saadeddine, S.; Meziane, M. Numerical investigation of thermohydraulic performance of air to water double-pipe heat exchanger with helical fins. Appl. Therm. Eng. 2017, 127, 127-139. [CrossRef]

70. Rubitherm Technologies GmbH. RT35 Data Sheet. Available online: https://www.rubitherm.eu/media/products/datasheets/ Techdata_-RT35_EN_09102020.PDF (accessed on 15 September 2021).

71. Talebizadeh Sardari, P.; Walker, G.S.; Gillott, M.; Grant, D.; Giddings, D. Numerical modelling of phase change material melting process embedded in porous media: Effect of heat storage size. Proc. Inst. Mech. Eng. Part A J. Power Energy 2019, 0957650919862974. [CrossRef]

72. Shahsavar, A.; Majidzadeh, A.H.; Mahani, R.B.; Talebizadehsardari, P. Entropy and Thermal performance Analysis of PCM Melting and Solidification Mechanisms in a Wavy Channel Triplex-Tube Heat Exchanger. Renew. Energy 2021, 165, 52-72. [CrossRef]

73. Al-Abidi, A.A.; Mat, S.; Sopian, K.; Sulaiman, M.Y.; Mohammad, A.T. Internal and external fin heat transfer enhancement technique for latent heat thermal energy storage in triplex tube heat exchangers. Appl. Therm. Eng. 2013, 53, 147-156. [CrossRef]

74. Mahdi, J.M. Enhancement of Phase Change Material (PCM) Thermal Energy Storage in Triplex-Tube Systems. Ph.D. Thesis, Southern Illinois University Carbondale, Carbondale, IL, USA, 2018. 